\title{
Comparison of the Tribological Properties of Fluorinated Cokes and Graphites
}

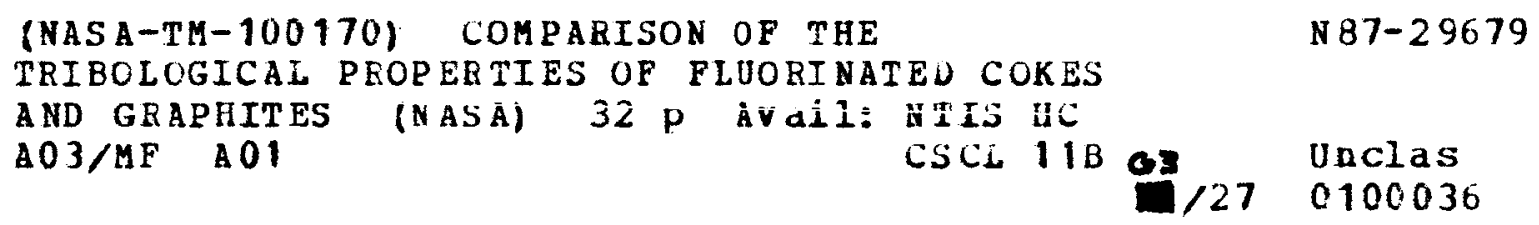

Robert L. Fusaro

Lewis Research Center

Cleveland, Ohio

Prepared for the 1988 Annual Meeting of the Society of Tribologists and Lubrication Engineers Cleveland, Ohio, May 9-12, 1988 
COMPARISON OF THE TRIBOLOGICAL PROPERTIES OF

FLUORINATED COKES AND GRAPHITES

\author{
Robert L. Fusaro \\ National Aeronautics and Space Administration \\ Lewis Research Center \\ Cleveland, Ohio 44135
}

\title{
Abstract
}

The friction, wear, endurance $11 f e$, and surface morphology of rubbed (burnished) fluorinated graphite and fluorinated coke materials were studied. Two different coke powders, a graphitic carbon powder, and a graphite powder were fluorinated and then tribologically investigated. In addition. one of the coke powders was reduced in size before fluorinating to evaluate the effect of a finer particle size on the tribological properties. For comparison, graphite and coke powders which were not fluorinated were also tribologically evaluated. Elemental analysis by emission spectroscopy was performed on each sample to determine the impurity content and $X$-ray diffraction analysis was performed to determine the crystallinity. Coke was found to have very little lubricating ability, but fluorinated coke did possess good lubricating properties. However, the fluorinated graphite and fluorinated graphitic carbon (which gave equivalent results) gave superior results to those obtained with the fluorinated cokes. No tribological benefit was found for using small versus a larger particle size of coke, at least when evaluated as a rubbed film.

\section{INTRODUCTION}

Fluorinated graphite $\left(\left(\mathrm{CF}_{x}\right)_{n}\right)$ has been shown to have very good lubricating properties under various conditions and types of applications. References 1 and 2 have shown that rubbed (burnished) films of it perform better than or equivalent to rubbed films of molybdenum disulfide $\left(\mathrm{MoS}_{2}\right)$ or 
graphite in tests conducted on a pin-on-disk machine. These rubbed film results were further improved by bonding the fluorinated graphite to the surfaces using a polyimide (3) or an organopolysiloxane (4) polymer. Besides thin films, other areas where good results have been obtained with fluorinated graphite are as additives to greases, to mechanical carbons, and to carbon fiber reinforced polytetrafluoroethylene (5). In Ref. 6, fluorinated graphite and various metals were simultaneously applied to a surface by using an electroplating bath.

One advantage of fluorinated graphite is that it functions much better in the absence of an adsorbable vapor (such as water vapor) than does graphite $(1,2,7)$. There are many applications for solid lubricants where there is a deficiency of water vapor, e.g., the vacuum of space. Thus, in addition to the many possible terrestrial applications, fluorinated graphite may also be a candidate for vacuum type lubrication applications such as those that might be encountered on the future NASA space station.

Several commercial sources are now available for obtaining the material; but the question remains, how important (to the tribological properties) is the starting material from which the fluorinated material is made? Some suppliers are selling fluorinated coke as a lubricant. How does this material compare to fluorinated graphite for lubrication applications?

The purpose of this investigation was to evaluate several different fluorinated graphite and coke materials to determine the effect of the starting material on the tribological properties. Two different fluorinated coke materials were evaluated, a fluorinated graphitic carbon material and a fluorinated graphite material. In addition, one of the coke materials was ground to a smaller particle size and then fluorinated to determine the effect of particle size on the tribological properties. For comparison, the same 
graphite material and one of the coke materials were tribologically evaluated in the nonfluorinated state. The fluorinated specimens and the nonfluorinated graphite were evaluated for impurities by emission spectroscopy and for crystallinity by powder $x$-ray diffraction. Tribological testing was conducted using a pin-on-disk tribometer with the powders being evaluated as rubbed (burnished) films applied to roughened 440C HT (high temperature) stainless steel disks. A $0.476 \mathrm{~mm}$ hemispherically tipped $440 \mathrm{C}$ HT stainless steel pin was slid against the film. Constant test conditions of an ambient temperature of $25 \pm 3{ }^{\circ} \mathrm{C}$, a load of $9.8 \mathrm{~N}$, a sliding speed of $2.7 \mathrm{~m} / \mathrm{s}(1000 \mathrm{rpm})$ were used. Since previous results $(1,2,7)$ indicated that similar endurance life and wear improvements between graphite and fluorinated graphite could be obtained with and without adsorbed vapors these experiments were conducted in moist air (50 percent relative humidity), the better condition for nonfluorinated graphite.

\section{MATERIALS}

It has been known for over a century that graphite forms compounds by the inclusion of foreign atoms within its structure $(8,9)$. Most of the compounds are ionic but the inclusion of fluorine atoms can produce a covalent compound. The compound is produced without combustion by a direct reaction with fluorine gas between the temperatures of 420 and $550^{\circ} \mathrm{C}$. For more information on the preparation see Refs. 7 to 12 .

The inclusion of the fluorine atoms expands the distance between the carbon layer planes from $0.34 \mathrm{~nm}$ to a value as great as $0.8 \mathrm{~nm}$. The carbon layer planes no longer remain planar but become "wavy". Ebert (13) has proposed a structure for the fluorinated graphite which consists of an infinite array of cis-trans-linked cyclohexane boats. Figure 1 shows his proposed structure for fluorinated graphite. How fluorine affects the structure of coke or carbon has not been studied. In this study, two 
different coke powders, a graphitic carbon powder and a graphite powder were fluorinated and tribologically evaluated. Table 1 lists the fluorinated materials evaluated and some of their properties.

The pin and the disk materials were $440 \mathrm{CHT}$ (high temperature) stainless steel) with hardness of Rockwell C-58. The surface roughness of the pin was less than $0.10 \mu \mathrm{m}$. The disk surfaces were sandblasted and then lightly polished on a polishing wheel to 1.1 to $1.2 \mu \mathrm{m}$ before application of the films. APPARATUS

A pin-on-disk tribometer was used to evaluate the rubbed films. The device has been described in detail in Ref. 14. A schematic of the test specimens is shown in Fig. 2. The friction specimens consisted of a rotating flat disk (6.3-cm diameter) and a stationary, hemispherically tipped pin (0.476-cm radius). The pin slid on a 5.0-cm-diameter track on the disk at a rotational speed of $1000 \mathrm{rpm}$ which translated into a linear sliding speed of $2.6 \mathrm{~m} / \mathrm{s}$.

The apparatus used to apply the films to the disks is shown in Fig. 3 . The disk was attached to the vertical shaft of a small electric motor by means of a cup-shaped holder. Two vertical rods were used to restrain a floating metal plate to which were attached the solid lubricant applicators (in this case polishing (loths). About $1 / 2 \mathrm{~g}$ of powder was applied to the rubbing zone of the applicators. The rubbing (burnishing) load was applied by placing two l-kg deadweights on top of the metal plate. The apparatus was covered with a bell jar and the atmosphere was controlled by purging with 50 percent relative humidity air. The rotational speed of the disk was $15 \mathrm{rpm}$ and the time of burnishing was $1 \mathrm{hr}$. For a more detailed description of the burnishing procedure see Ref. 14. 


\section{TESTING PROCEDURE}

The disk surfaces were cleaned by washing with ethyl alcohol before sandblasting. After sandblasting they were scrubbed with a brush under running water to remove any adhering sand particies. The surfaces were then lightly rubbed on a polishing wheel using a water paste of levigated alumina to remove the sharp sandblasted asperities tips. Again they were scrubbed with a brush under running water to remove any adhering levigated alumina powder. Clean, dry air was used to quickly dry the surfaces. The solid lubricant powders were then applied to the sandblasted surface using the burnishing apparatus which was previously described.

The pins were washed with ethyl alcohol and then scrubbed with a water paste of levigated alumina. They were then rinsed in distilled water and dried with clean, dry compressed air. Solid lubricant films were not applied to the pins.

After cleaning and coating, the specimens were inserted into the tribometer, and the chamber sealed. Moist air of 50 percent relative humidity at $25^{\circ} \mathrm{C}$ was purged through the chamber of $2000 \mathrm{~cm}^{3}$ at the rate of $1500 \mathrm{~cm}^{3} / \mathrm{min}$ for $15 \mathrm{~min}$ before commencing each test. The disk was set into rotation at $1000 \mathrm{rpm}(2.6 \mathrm{~m} / \mathrm{s})$ and a $9.8 \mathrm{~N}$ load was gradually applied. The test temperature was ambient $\left(25 \pm 3^{\circ} \mathrm{C}\right)$. Each test was stopped after $1 \mathrm{kc}$ of sliding $(0.16 \mathrm{~km})$ and pin wear volume was determined. Pin wear rate was calculated for this interval and was deemed to be the "run-in" wear rate.

Each test was also stopped after various other sliding intervals so that wear volume could be measured and surface morphology could be studied by optical microscopy. After studying the surfaces, the specimens were remounted into the tribometer, and the test procedure repeated. The pin was not removed 
from its holder, and locating pins ensured that it was returned to its original position.

\section{RESULTS AND DISCUSSION}

\section{Impurity Analysis}

An emission spectrometer was used to determine the amount and type of impurity elements in the fluorinated coke and graphite samples. The samples were covered with ethanol to wet them, then aqua-regia and hydrofluoric acid were added to leach the impurities. The "leach" was analized, so only the acid soluble impurities were detected. Table 2 lists the elements and the amount found in each fluorinated sample and in the nonfluorinated graphite sample.

All the fluorinated samples contained a large amount of chromium. It is thought that chromium may have been picked up from the thermocouple during the fluorination process since the nonfluorinated graphite sample contained very little. Zirconium was also higher in the fluorinated graphite than in the nonfluorinated graphite, but there was very little zirconium in the other fluorinated samples. Not knowing the history of the samples, it is impossible to say why this occurred. Cobalt was also found to be higher in the fluorinated rather than in the nonfluorinated graphites. The amount of some elements in the fluorinated graphite decreased with respect to that found in the nonfluorinated graphite. For instance calcium decreased from 80 to $40 \mathrm{ppm}$ and magnesium decreased from 270 to $10 \mathrm{ppm}$.

Comparing the elements which were present in each of the fluorinated graphites and cokes, there is no clear trend that indicates that a particular elemental impurity was beneficial or detrimental to the tribological properties of the burnished films. It is not believed that these impurity elements significantly affected the tribological results. 
Crystallinity Analysis

Powder x-ray diffraction patterns were taken of each sample using copper Ka radiation. Figure 4 presents the intensity of the radiation from the fluorinated samples versus the two-theta angle of the goniometer for a range of 10 to $20^{\circ}$. Figure 5 shows the same data for a two-theta range of 20 to $80^{\circ}$. Graphite is also included in this figure for comparison. The data shows that the graphite is of good quality with very sharp, distinctive peaks. The peaks of the fluorinated samples are not as sharp as the graphite, but the patterns are in agreement with the "wavy nature" of the carbon atoms in the hexagonal layer plains imparted by the covalently boned fluorine atoms. The peaks of the fluorinated graphite and graphitic carbon are somewhat more distinct than the fluorinated coke, indicating it is slightly more crystalline.

The interlayer distance between the planes was calculated using Bragg's Law from the two-theta values (Table 3). The interlayer distance for all the fluorinated samples was increased compared to the nonfluorinated graphite. The interlayer distance for the fluorinated cokes tended to be increased more than the fluorinated graphitic materials, this is most likely because they were more highly fluorinated than the graphitic materials.

\section{Endurance Life}

Figure 6 gives endurance life for the 6 different samples evaluated. Endurance life is defined as the number of sliding cycles (expressed in kilocycles in the text) to reach a friction coefficient of 0.30 . At least three tests for each sample were conducted and the open part of the bar in Fig. 6 represents the scatter. The fluorinated graphite gave the longest endurance life, with a mean life of $1170 \mathrm{kc}$. The fluorinated graphitic carbon was next with a meanlife of $850 \mathrm{kc}$. The longest endurance life for any of the fluorinated cokes tested was $400 \mathrm{kc}$ while the shortest life was $150 \mathrm{kc}$. 
All fluorinated materials (whether coke or graphite) gave considerably better endurance lives, than the nonfluorinated graphite, which gave an endurance life of 50 to $60 \mathrm{kc}$ under these particular sliding conditions. Type 1 coke (nonfluorinated) was also evaluated, but the friction coefficient rose immediately to 0.40 and by the definition of endurance life in this study it had zero life. Even so, the test on the coke was continued for $2 \mathrm{kc}$ of sliding to determine wear and friction values.

\section{Friction Coefficient}

Figure 7 gives the friction coefficient as a function of sliding duration for all the materials for the first $40 \mathrm{kc}$ of sliding, and Fig. 8 gives the same friction information for the complete endurance life. As mentioned in the previous section, nonfluorinated coke was also evaluated, but the test was run for too short an interval to be included in Fig. 7. The friction coefficient obtained for this material was $0.38 \pm 0.03$.

The friction coefficients for the other materials varied from test to test and sample to sample but the friction traces presented in Figs. 7 and 8 are representative of the general friction trends that occurred. All samples (including the nonfluorinated graphite) started out at a friction coefficient value which was between 0.10 and 0.16 . The friction coefficient of the nonfluorinated graphite rose very rapidly from this initial value to a value greater than 0.2 , but then rose in a more gradual manner with sliding distance until failure occurred. For the first $15 \mathrm{kc}$ of sliding, the friction coefficients for the fluorinated graphites and cokes were nearly identical, but after this point the fluorinated cokes tended to increase to a higher friction coefficient value at a more rapid rate than did the fluorinated graphite samples. The fluorinated graphite tended to stay under a friction coefficient value of 0.20 for $1000 \mathrm{kc}$ of sliding and the graphitic carbon for 
$800 \mathrm{kc}$ of sliding. The fluorinated cokes tended to reach a friction coefficient value of 0.2 before $50 \mathrm{kc}$ of sliding. Possible reasons for the friction variations will be discussed in a later section.

\section{Pin Wear}

Pin wear volume as a function of sliding distance in kflometers is plotted in Fig. 9. Pin wear was plotted as a function of sliding distance rather than sliding revolutions since the pin was in continuous contact with the disk and thus was more dependent on the total distance slid rather than the number of kilocycles traversed. Endurance life and friction coefficient were plotted as a function of repeated cycles, since the lubricant on the disk was in intermittent contact with the pin, and thus these quantities were more dependent on repeated passes over an individual area than on total distance slid.

For the first 5 to $7 \mathrm{~km}$ of sliding, there was little difference in the pin wear volumes obtained for the fluorinated graphites, fluorinated cokes or even the nonfluorinated graphite. But beyond this point, the pin wear obtained for all the films except the fluorinated graphite and the fluorinated graphitic carbon tended to increase with increasing sliding distance. And as the sliding distance approached the endurance life of a particular film, the pin wear rate increased at a more rapid rate.

Run-in and steady-state pin wear rates (calculated from curves like those in Fig. 9) are plotted in fig. 10. Run-in wear rate was defined in this study to be the pin wear that occurred from 0 to $1 \mathrm{kc}$ of sliding $(0.16 \mathrm{~km})$. Pin wear rates, calculated for the sliding interval of 1 to $10 \mathrm{kc}$, were found to be in the steady-state wear value regime; thus it appears that most of the run-in pin wear took place during the first kc of sliding. The run-in pin wear rates for nonfluorinated graphite and all the fluorinated graphites and 
cokes were found to be nearly equal (Fig. 10). The one exception might be the fluorinated type 2 coke which gave slightly higher pin run-in wear rate values.

Steady-state pin wear was defined as the linear portion of the curves in Fig. 9 which occurred after run-in. The fluorinated graphite and fluorinated graphitic carbon gave an equivalent steady-state pin wear rate of $(2 \pm 1) \times 10^{-16} \mathrm{~m}^{3} / \mathrm{m}$ of sliding. The steady-state pin wear rate obtained with both type 1 and 2 fluorinated coke films was $(3 \pm 2) \times 10^{-16} \mathrm{~m}^{3} / \mathrm{m}$ and the wear rate obtained with the nonfluorinated graphite film was $(7 \pm 6) \times 10^{-16} \mathrm{~m}^{3} / \mathrm{m}$. The coke (nonfluorinated) films gave a pin wear rate of $(1.0 \pm 0.3) \times 10^{-14} \mathrm{~m}^{3} / \mathrm{m}$ after sliding intervals of both 1 and $2 \mathrm{kc}$ of sliding. Unlubricated $440 \mathrm{CHT}$ stainiess steel sliding on itself gave a wear rate of about $1 \times 10^{-8} \mathrm{~m}^{3} / \mathrm{m}$ of sliding, thus even the coke (nonfluorinated) gave good pin wear protection for a short period of time.

\section{Film Wear Track Morphology}

Figures 11 to 14 show visual light photomicrographs of the film wear track surfaces after various sliding intervals. Both the nonfluorinated graphite film (Fig. $I(a)$ ) and the fluorinated graphite film (Fig. 12(a)) show good bonding to the surface after $10 \mathrm{kc}$ of sliding. However, the nonfluorinated graphite film does show more cracking, blistering, and spalling than does the fluorinated graphite film. This was found to be especially true on continued sliding, the nonfluorinated graphite film gradually became depleted from the surface and at failure (a friction coefficient of 0.30 ) large void areas could be seen within the film wear track area which were filled with powdery wear debris (Fig. $11(b))$.

The fluorinated graphite film tended to crack and bijster much less than the nonfluorinated graphite film under the conditions of these experiments. Even after $600 \mathrm{kC}$ of sliding (Fig. 12(b)) on the fluorinated graphite film, a 
good compacted supply of the material was present between the metallic asperities of the substrate. These compacted material areas served as reservoirs to supply lubricant to the metallic asperity plateaus. The fluorinated graphitic carbon produced films similar to those obtained with the fluorinated graphite.

The coke powder (nonfluorinated) did not form a good lubricating layer on the metallic disks under sliding conditions. No smooth, continuous lubricant film was produced. Figure 13 shows a photomicrograph of the wear track on the coke film after $1 \mathrm{kc}$ of sliding. Large voided areas are seen in the wear track, and the small amount of coke material that is present is closely packed around the metallic asperity plateaus. Some thin films of coke were observed on the metallic asperity plateaus, which it appears did help mitigate the wear.

Fluorination of the coke tended to make it into a solid lubricant and to improve its ability to adhere to the wear track surface. Figure 14 shows the wear track on a fluorinated type 1 coke film after 1 and $60 \mathrm{kc}$ of sliding. The fluorinated type 2 coke wear surfaces looked very similar. Considerably more fluorinated coke was present on the surface than was found for the nonfluorinated coke, but the film was somewhat more powdery looking than the fluorinated graphite, fluorinated graphitic carbon, or the nonfluorinated graphite film. Also, some cracking and spalling of the film in the wear track area can be seen after only $1 \mathrm{kc}$ of sliding. It is postulated that the reason why the fluorinated coke films provided longer endurance lives than graphite (nonfluorinated) was that fluorinated coke tended to remain bonded to the metallic substrate for a longer period of time than did the graphite. Transfer Film Morphology

Nonfluorinated coke tended not to form transfer films on the sliding pin surfaces. However, all the fluorinated materials and the nonfluorinated 
graphite did form transfer films on the pin wear scars, although there were some differences in the appearance of the films. Figure 15 gives some low magnification photomicrographs of the pin wear scar areas after $1 \mathrm{kc}$ of sliding for pins that slid on rubbed films of (a) nonfluorinated graphite, (b) fluorinated graphite, (c) fluorinated coke, and (d) fluorinated small particle coke. Figures 16,17 , and 18 respectively give high magnification photomicrographs of the transfer films on the wear scars on the graphite, the fluorinated graphite, and the fluorinated coke pin surfaces. The fluorinated graphitic carbon transfer films looked similar to the fluorinated graphite transfer films and all the fluorinated coke transfer films looked similar to those shown in Fig. 18 .

In general, the fluorinated materials tended to build up in the pin inlet region more than did the nonfluorinated graphite and the transfer to the pin appeared to be less streaky (Fig. 15). In addition, the fluorinated graphite and fluorinated graphitic carbon seemed to possess better rheological properties than the fluorinated coke materials. The fluorinated graphite material which built up in the inlet region produced interference fringes which indicated the material was transparent and that it had flowed together to produce a continuous surface that could reflect light (Fig. 15(b)).

Initially, the nonfluorinated graphite transfer films were very thin (Fig. 16(a)) and on continued sliding they tended to get thicker (Fig. 16(b)); but then as the film on the wear track became depleted (Fig. $11(b)$ ), they thinned down again. The fluorinated graphite and fluorinated graphitic carbon transfer films were initially even thinner than the graphite transfer films and like the nonfluorinated graphite films they tended to get thicker on continued sliding (Fig. 17(b)). However, the fluorinated graphite films did not get as thick as the nonfluorinated graphite films, and they appeared to be 
more continuous and better bonded than the nonfluorinated graphite transfer films.

The fluorinated coke transfer films (Fig. 18) were initially thicker than the fluorinated graphite films (Fig. 17); but on continued sliding they tended to get thinner. This was probably due to the fact that the film on the wear track tended to debond from the disk wear track (with continued sliding (Fig. 14)) and insufficient material was available for transfer film formation. Thus, transfer film formation tended to be related to how much lubricant was available on the disk wear track.

\section{CONCLUDING REMARKS}

The results indicate that the fluorination of graphite and coke improves the ability of these materials to adhere to a sliding interface. Bonding of a material is a priority if a material is going to provide good lubrication. The results also indicate improved bonding and lubricating ability are achieved by fluorination of the more crystalline form of carbon (graphite) rather than with the amorphous form of carbon (coke). This may be due to graphite's ability to more easily orient itself on the surface since it is crystalline. The hexagonal planes of different graphite crystals are able to "flow into one another" whereas the amorphous coke cannot do this as easily.

An analogy of what is happening in a good lubrication situation might be compared to several decks of cards piled up on a table. The decks represent individual crystals of graphite, the cards represent crystalline planes. Imagine that the individual cards are loosely glued together in the deck, somewhat like a hexagonal crystal. If you were to slide your fist back and forth in the same area across this pile of decks, they would spread out on the table and eventually the packs would be knocked flat on the table. Continued sliding over the packs would loosen some of the individual cards and 
eventualiy cards from one deck would slide into another deck. Before long all the cards would be mixed on the surface. As sliding continued the cards would tend to slide over one another, but some would tend to slide out of the contact of the sides of the rubbing area and eventually the contact area would become depleted. This may be an over simplistic view of what happens during the "rubbed film" lubrication process but from the author's experience, it seems to be systematic of what is happening.

\section{CONCLUSIONS}

Friction, wear, and surface morphology studies conducted on rubbed films of nonfluorinated graphite, nonfluorinated coke, fluorinated graphite, fluorinated graphitic carbon, and two types of fluorinated cokes indicated that:

1. Fluorinated graphite or fluorinated graphitic carbon gave superior lubrication performance when compared to the same graphite which was nonfluorinated or to fluorinated coke.

2. Fluorination of coke imparted some lubrication ability which the nonfluorinated coke did not have.

3. Initial (up to $17 \mathrm{kc}$ of sliding) friction coefficients and wear rates of fluorinated graphite and fluorinated coke were nearly identical, but after this point fluorinated graphite was much superior. In addition, the endurance life of fluorinated graphite was up to 5 times greater than fluorinated coke.

4. A tribological advantage of fluorinated graphite as compared to fluorinated coke or to nonfluorinated graphite was that it adhered to the metallic substrate better than the other two and thus promoted a longer endurance life.

5. Rheologically, the fluorinated graphite tended to show better properties than fluorinated coke or nonfluorinated graphite. It produced 
better adhering, more continuous wear track films and transfer films to the pin wear scar than the other two.

6. A smaller particle size of the fluorinated coke showed equivalent tribological properties when compared to the larger size fluorinated coke particle.

\section{ACKNOWLEDGMENTS}

The author would like to thank Larry Bobbin of Allied-Signal Corporation for providing the graphite, coke, and fluorinated graphite and coke samples and for his helpful consultaions. Thanks are also in order to Ralph Garlick and Fran Archer of NASA Lewis Research Center for conducting respectively the $x$-ray diffraction and emission spectroscopy studies.

\section{REFERENCES}

1. Fusaro, R.L., and Sliney, H.E., "Graphite Fluoride - A New Solid Lubricant," ASLE Trans., 13, pp. 56-65 (1970).

2. Fusaro, R.L., "Graphite Fluoride Lubrication: The Effect of Fluoride Content, Atmosphere, and Burnishing Technique," ASLE Trans., 20, pp. 15-24 (1977).

3. Fusaro, R.L., "Polyimide Dry Films and Composites in Tribology," Solid and Liquid Lubricants for Extreme Environments, ASLE SP-15, ASLE, (1984) pp. 14-24.

4. Fusaro, R.L., "Organopolysiloxane-Bonded Graphite Fluoride as a Solid Lubricant," NASA TN D-6714 (1972).

5. Ishikawa, T., Teranishi, H., and Morishita, M., "Carbon Fibers, and Compsoite Materials of Carbon Fibre and Polytetrafluoroethylene," Carbon Fibres: Their Composites and Applications, Plastics Institute, London (1971) Paper no. 35. 
6. Tsuya, Y., Uemura, H., Okamoto, Y., and Kurosaki, S., "Codeposited Composite Metal-Graphite Fluoride Platings," ASLE Trans., 17, pp. 229-235 (1974).

7. Fusaro, R.L., "Graphite Fluoride Lubrication: The Effect of Fluorine Content, Atmosphere, and Burnishing Technique," ASLE Trans., 20, pp. 15-24 (1977).

8. Croft, R.C., "Lameller Compounds of Graphite," Quarterly Revs. (London), 14, pp. 1-45, (1960).

9. Hoffmann, U., "Graphite and Graphite Compounds," Ergeb. Exakt. Naturw., 18, pp. 229-256 (1939).

10. Ruff, 0., Bretschneider, O., and Ebert, F., "The Reaction Products of the Various Forms of Carbon with Fluorine. II. Carbon Monofluorine," $\underline{Z}$. Anorg. Allgem. Chem., 217, pp. 1-19 (1934).

11. Bigelow, L.A., "The Action of Elementary Flourine Upon Organic Compounds," Chem. Rev., 40, pp. 51-115 (1947).

12. Kurikose, A.K., and Margrave, J.L., "Kinetics of the Reactions of Elemental Fluorine. IV. Fluorination of Graphite," J. Phys. Chem., 69, pp. 2772-2775 (1965).

13. Ebert, L.B., Brauman, J.I., and Huggins, R.A., "Carbon Monofluoride: Evidence for a Structure Containing an Infinite Array of Cyclohexane Boats," J. Am. Chem. Soc., 96, pp. 7841-7842 (1974).

14. Fusaro, R.L., "How to Evaluate Solid-Lubricant Films Using a Pin-on-Dish Tribometer," Lubr. Eng., 43, pp. 330-338 (1987). 
TABLE ?. - SOME PROPERTIES OF THE DIFFERENT FLUORINATED GRAPHITES AND COKES EVALUATED IN THIS STUDY

\begin{tabular}{|l|c|c|}
\hline Fluorinated material & $\begin{array}{c}\text { Average particle size } \\
\text { of starting material, } \\
\mu \mathrm{m}\end{array}$ & $\begin{array}{c}\text { Fluorine to carbon ratio } \\
\text { after fluorination }\end{array}$ \\
\hline Coke, type 1 & 0.7 & 1.0 \\
Coke, type 1 & .2 & 1.1 \\
(small particle size) & 12.0 & 1.0 \\
Coke, type 2 & 5.0 & .7 \\
Graphite & 5.0 & .9 \\
Graphitic carbon & & \\
\hline
\end{tabular}

TABLE 2. - ELEMENTAL ANALYSIS OF GRAPHITE AND FIVE DIFFERENT TYPES OF FLUORINATED GRAPHITES AND COKES BY EMISSION SPECTROSCOPY

[Concentration, parts per million (ppm).]

\begin{tabular}{|c|c|c|c|c|c|c|}
\hline \multirow{3}{*}{$\begin{array}{l}\text { El ement } \\
\text { type }\end{array}$} & \multicolumn{6}{|c|}{ Material type } \\
\hline & \multirow{2}{*}{$\begin{array}{c}\text { Nonfluorinated } \\
\text { graphite }\end{array}$} & \multicolumn{5}{|c|}{ Fluorinated material } \\
\hline & & Graphite & $\begin{array}{l}\text { Graphitic } \\
\text { carbon }\end{array}$ & $\begin{array}{l}\text { Coke, } \\
\text { type } 2\end{array}$ & $\begin{array}{l}\text { Coke, } \\
\text { type }\end{array}$ & $\begin{array}{l}\text { Coke, } \\
\text { type } 1 \\
\text { small } \\
\text { particle }\end{array}$ \\
\hline $\begin{array}{l}\mathrm{Al} \\
\mathrm{Bn} \\
\mathrm{Ba} \\
\mathrm{Ca} \\
\mathrm{Co} \\
\mathrm{Cr} \\
\mathrm{Cu} \\
\mathrm{Fe} \\
\mathrm{Mg} \\
\mathrm{Mn} \\
\mathrm{Ni} \\
\mathrm{Si} \\
\mathrm{Ti} \\
\mathrm{Zn} \\
\mathrm{Zr}\end{array}$ & $\begin{array}{c}<0.005 \\
<.001 \\
<.001 \\
80 \\
<.01 \\
<.005 \\
<.02 \\
280 \\
270 \\
<.01 \\
<.05 \\
<.01 \\
<.003 \\
<.003 \\
<.001\end{array}$ & $\begin{array}{c}<0.005 \\
<.001 \\
<.001 \\
40 \\
<5 \\
360 \\
<.02 \\
210 \\
10 \\
0.01 \\
<.05 \\
<.01 \\
<.003 \\
<.003 \\
70\end{array}$ & $\begin{array}{c}<0.005 \\
<0.001 \\
<0.001 \\
10 \\
5 \\
50 \\
<.02 \\
150 \\
<.005 \\
<.01 \\
<.05 \\
<.01 \\
<.003 \\
<.003 \\
<.001\end{array}$ & $\begin{array}{c}60 \\
<.001 \\
60 \\
<.001 \\
<.01 \\
60 \\
<.2 \\
470 \\
<.005 \\
<.01 \\
<.05 \\
.01 \\
<.003 \\
<5 \\
<.001\end{array}$ & $\begin{array}{c}40 \\
<0.001 \\
<.001 \\
130 \\
<.01 \\
50 \\
<.02 \\
300 \\
30 \\
<.01 \\
<.05 \\
<.01 \\
10 \\
<.003 \\
<.001\end{array}$ & $\begin{array}{c}<0.005 \\
<.001 \\
<.001 \\
30 \\
<.01 \\
160 \\
<.02 \\
240 \\
30 \\
<.01 \\
<.05 \\
<.01 \\
<.003 \\
<.003 \\
<.001\end{array}$ \\
\hline
\end{tabular}

TABLE 3. - SUMMARY OF X-RAY DIFFRACTION DATA ON GRAPHITE AND ON THE FLUORINATED GRAPHITES AND COKES

\begin{tabular}{|c|c|c|}
\hline Material type & $\begin{array}{l}\text { Two-theta angle, } \\
\text { deg }\end{array}$ & $\begin{array}{c}\text { Distance between } \\
\text { carbon layer planes, } \\
\text { nm }\end{array}$ \\
\hline $\begin{array}{l}\text { Graphite } \\
\text { Fluorinated graphite } \\
\text { Fluorinated } \\
\text { graphitic carbon } \\
\text { Fluorinated coke, } \\
\text { type } 1 \\
\text { Fluorinated coke, } \\
\text { type } 1 \text { (small particle) } \\
\text { Fluorinated coke, } \\
\text { type } 2\end{array}$ & $\begin{array}{l}26.4 \\
14.2 \\
14.1 \\
12.5 \\
12.7 \\
11.8\end{array}$ & $\begin{array}{r}0.337 \\
.624 \\
.629 \\
.708 \\
.697 \\
.749\end{array}$ \\
\hline
\end{tabular}



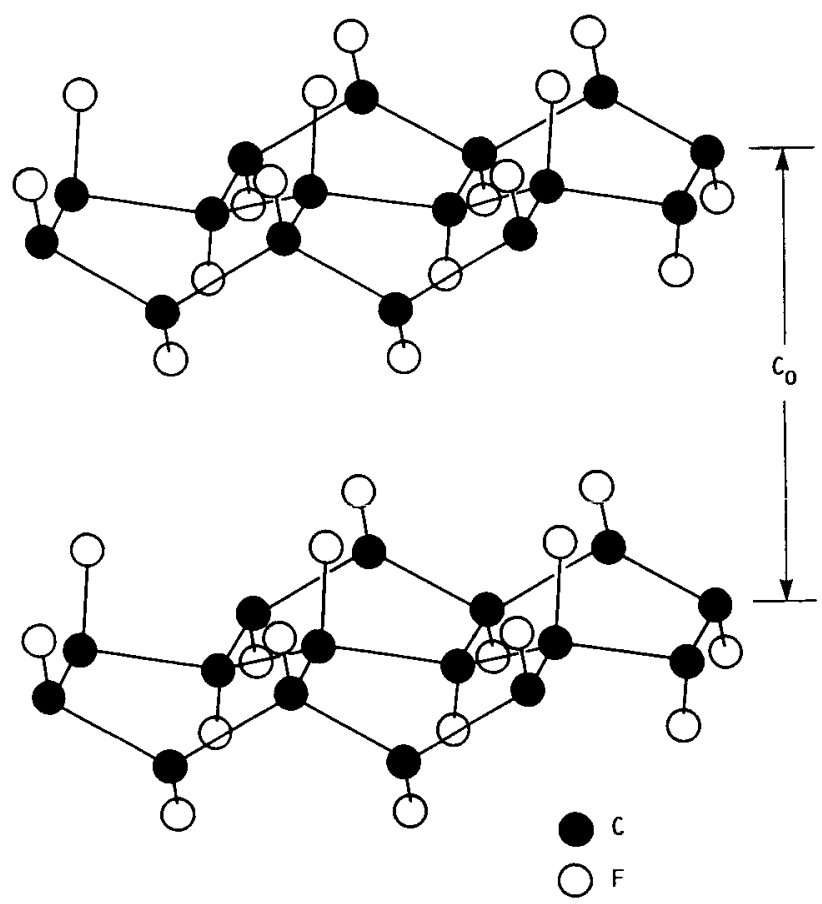

FIGURE 1. - PROPOSED STRUCTURE OF FLUORINATED GRAPHITE COMPOSED OF AN INF INITE ARRAY OF CIS-TRANS-LIMKED CYCLOHEXANE BOATS. (REF. 12).

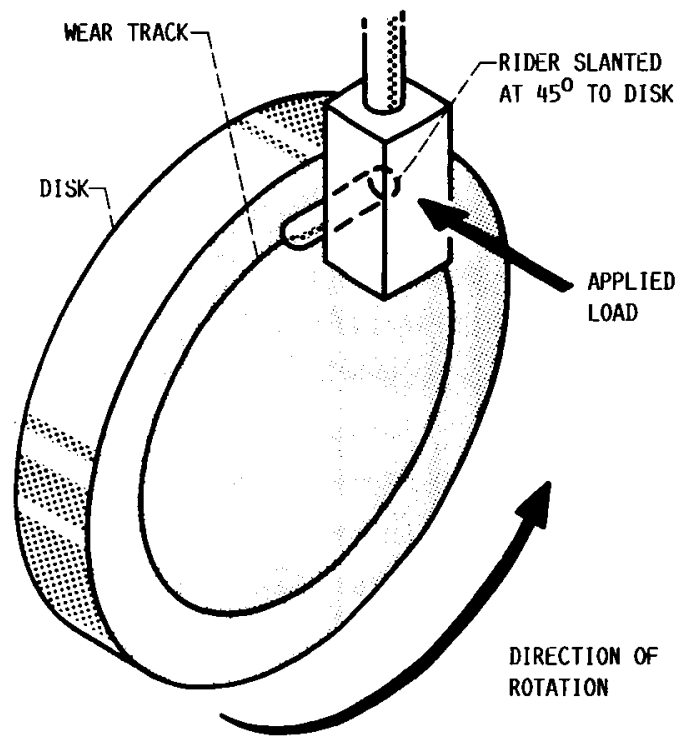

FIGURE 2. - SCHEMATIC DIAGRAM OF FRICTION SPECIMENS.

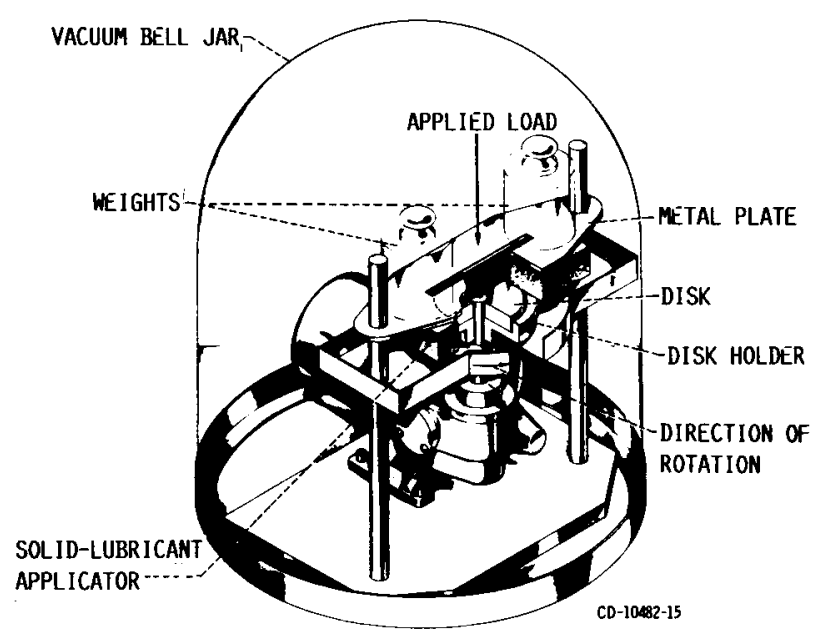

FIGURE 3. - BURNISHING APPARATUS. 


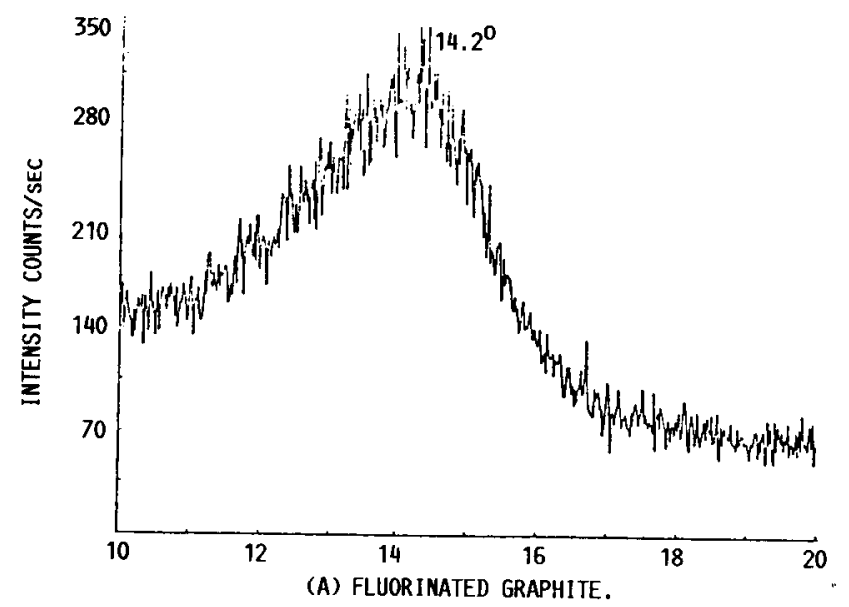

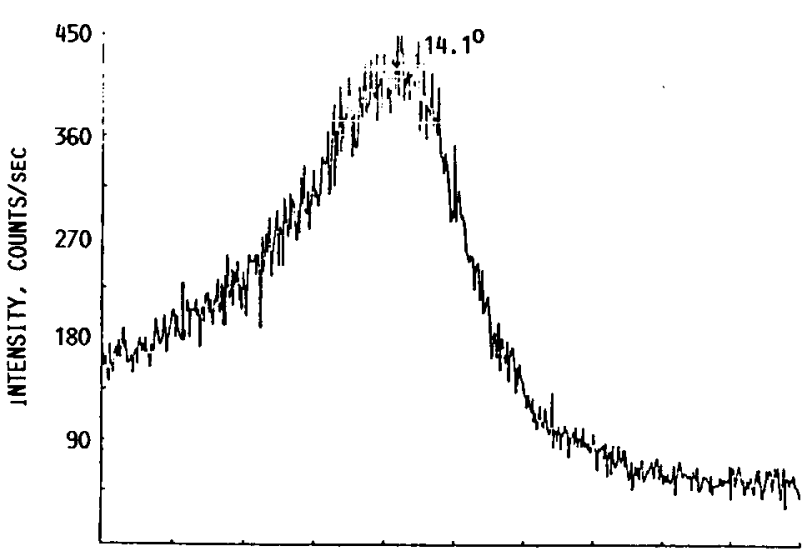

(B) FLUORINATED GRAPHITIC CARBON.

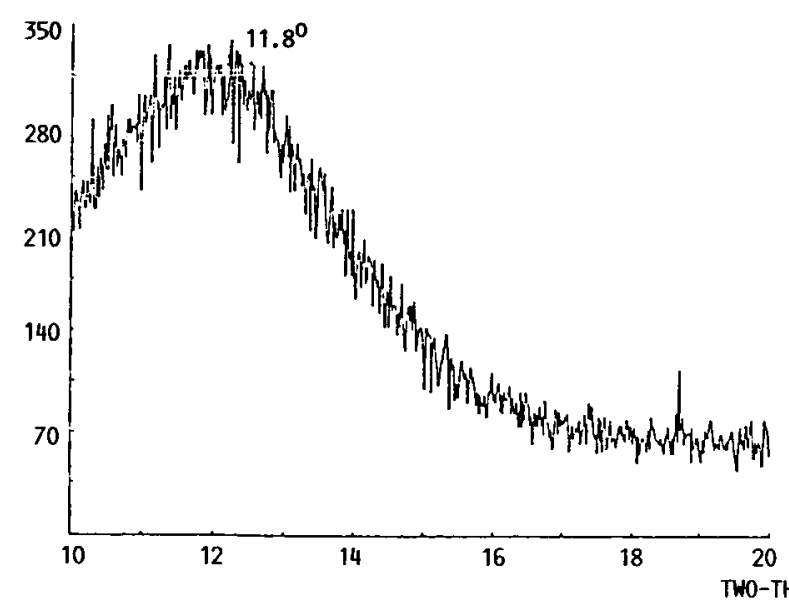

(D) FLUORINATED COKE, TYPE 2.

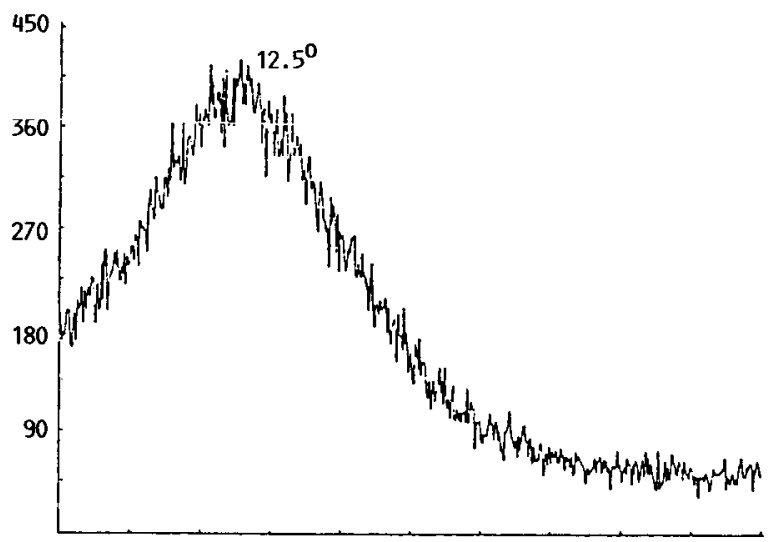

(C) FLUORINATED COKE, TYPE 1.

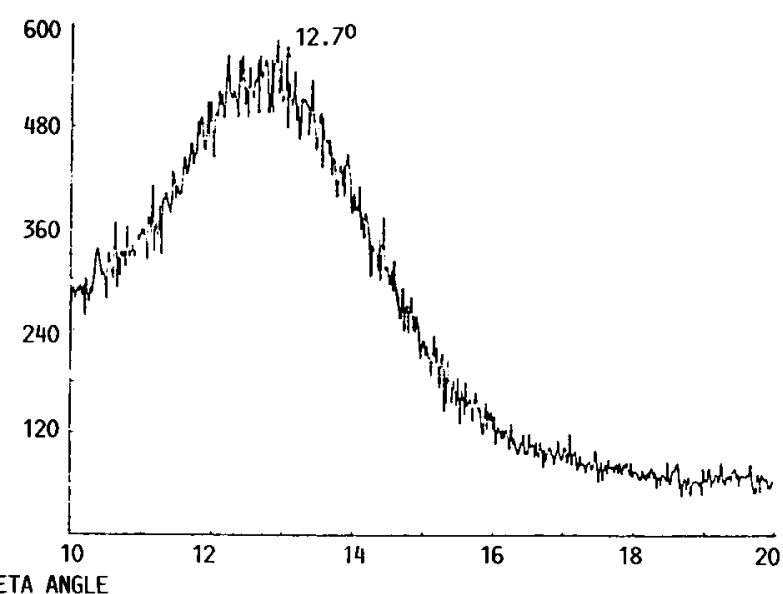

(E) FLUORINATED COKE, TYPE $\uparrow$ (SMALL PARTICLE SIZE),

FIGURE 4. - X-RAY DIFFRACTION PATTERNS OF FLUORINATED GRAPHITES AND FLUORINATED COKES FOR TWO-THETA ANGLES OF 100 TO $20^{\circ}$. 


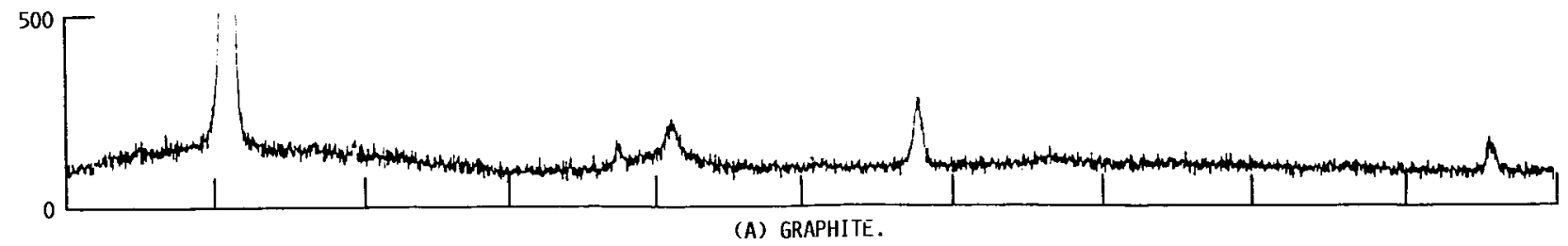

(A) GRAPHITE.

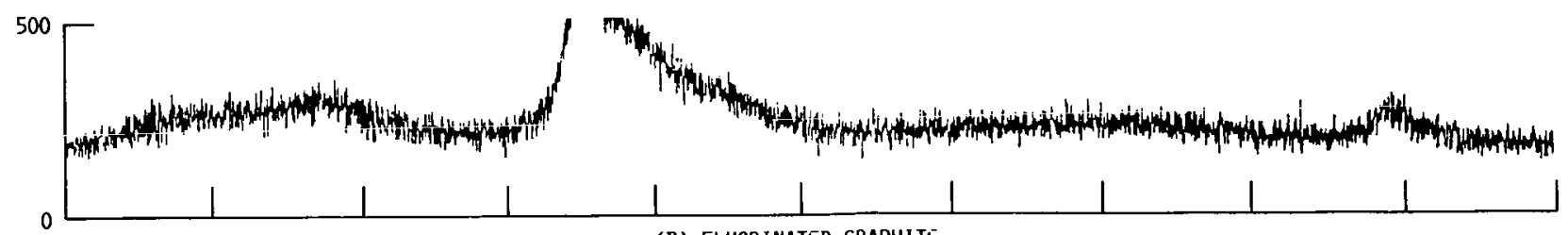

(B) FLUORINATED GRAPHITE.

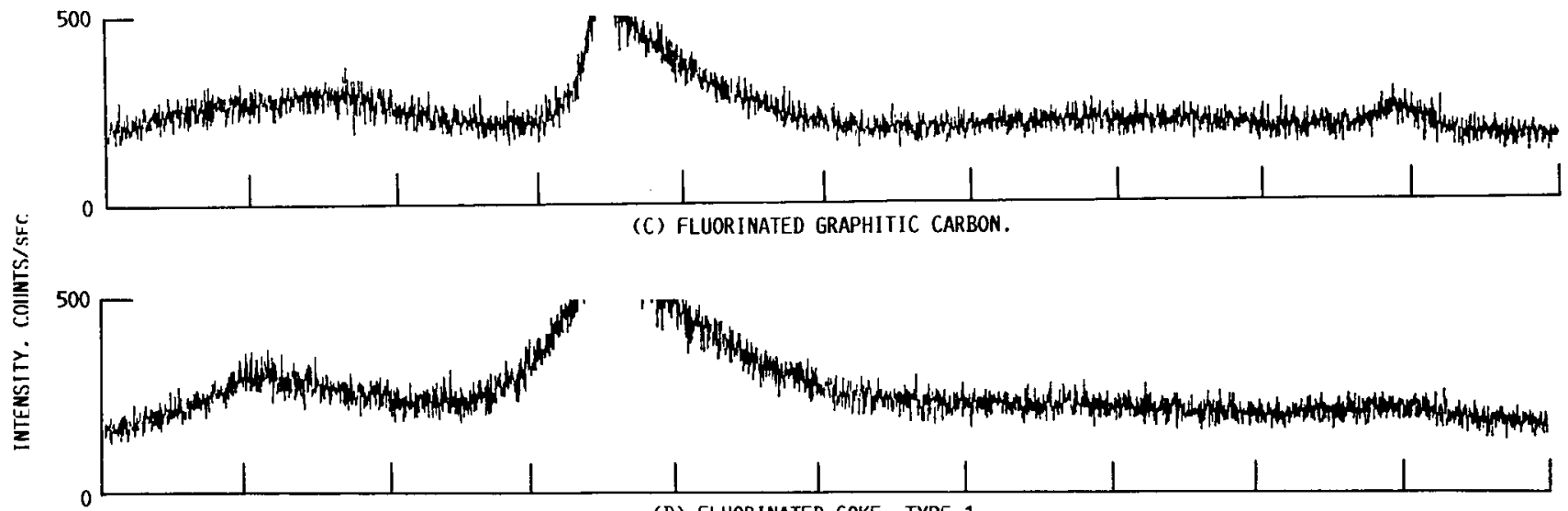

(D) FLUORINATED COKE, TYPE 1.

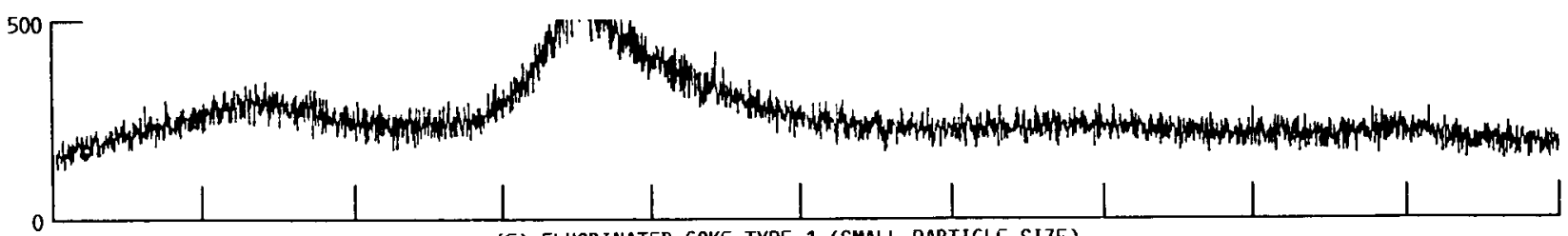

(E) FLUORINATED COKE TYPE 1 (SMALL PARTICLE SIZE).

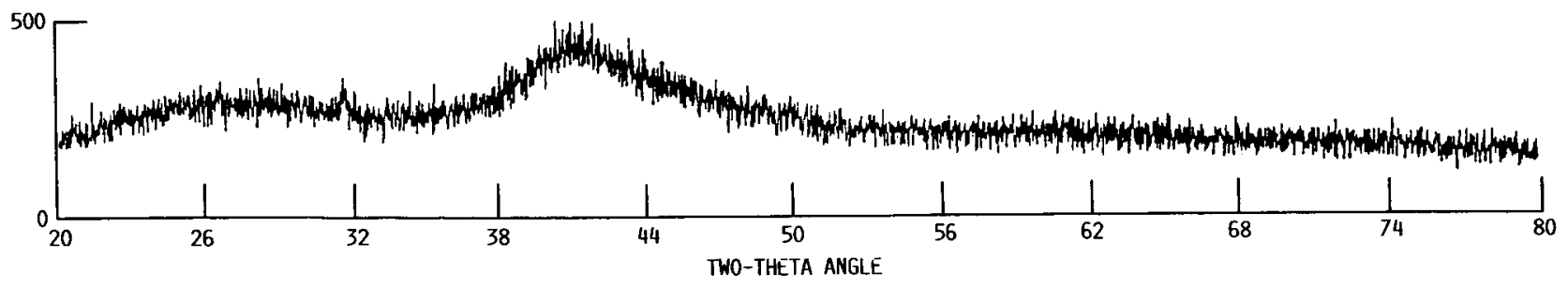

(F) FLUORINATED COKE TYPE 2.

FigURE 5. - X-RAY DIFFRACTION PATTERNS OF GRAPHITE AND FLUORINATED GRAPHITES AND COKE FOR TWO-THETA ANGLES OF $20^{\circ}$ TO $80^{\circ}$. 


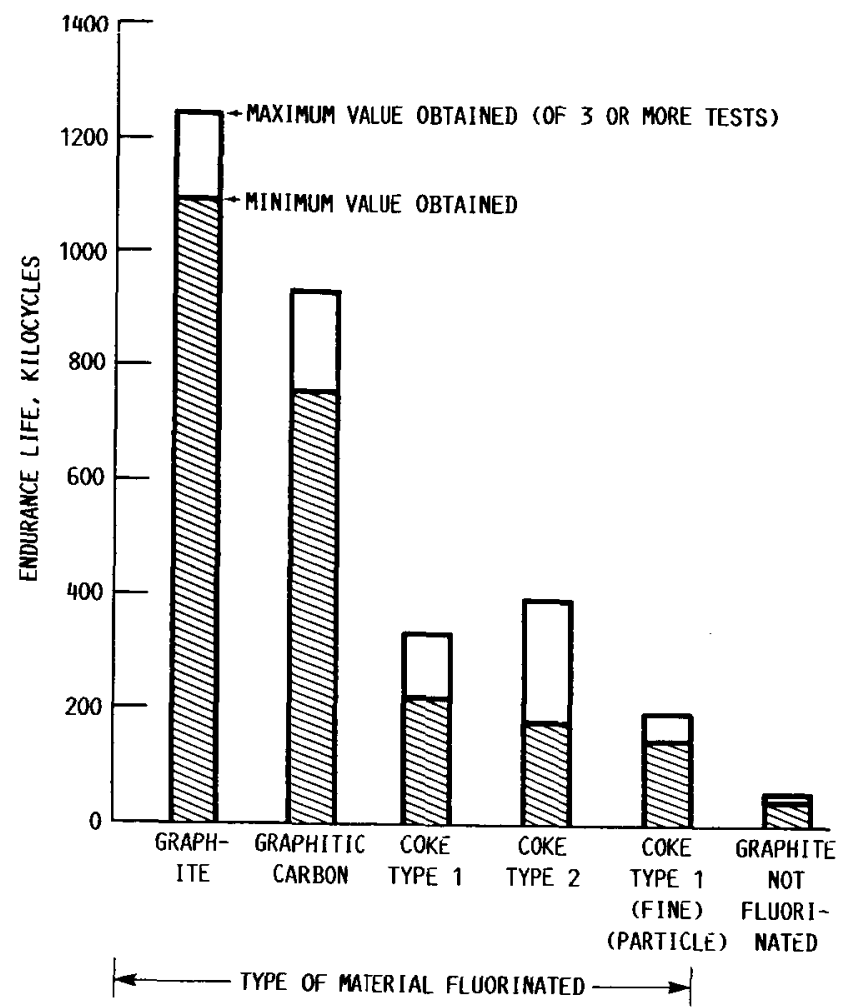

FIGURE 6. - ENDURANCE LIFE FOR FIVE DIFFERENT TYPES OF GRAPHITE AND COKE WHICH HERE FLUORINATED TO PRODUCE A CF TYPE OF MATERIAL. THE SAME TYPE OF GRAPHITE BUT NOT FLUORINATED IS SHOWN AS A COMPARISON.

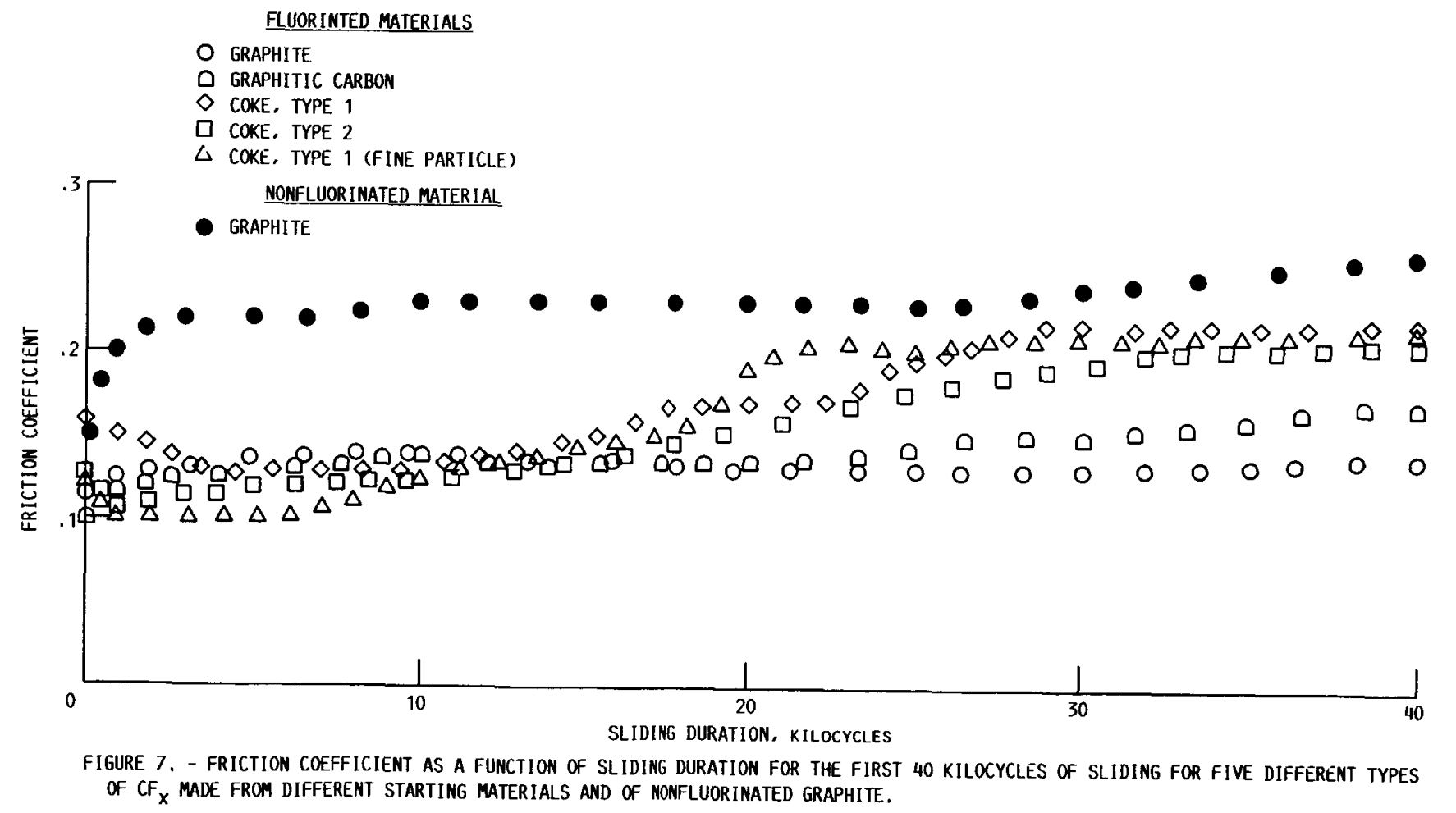




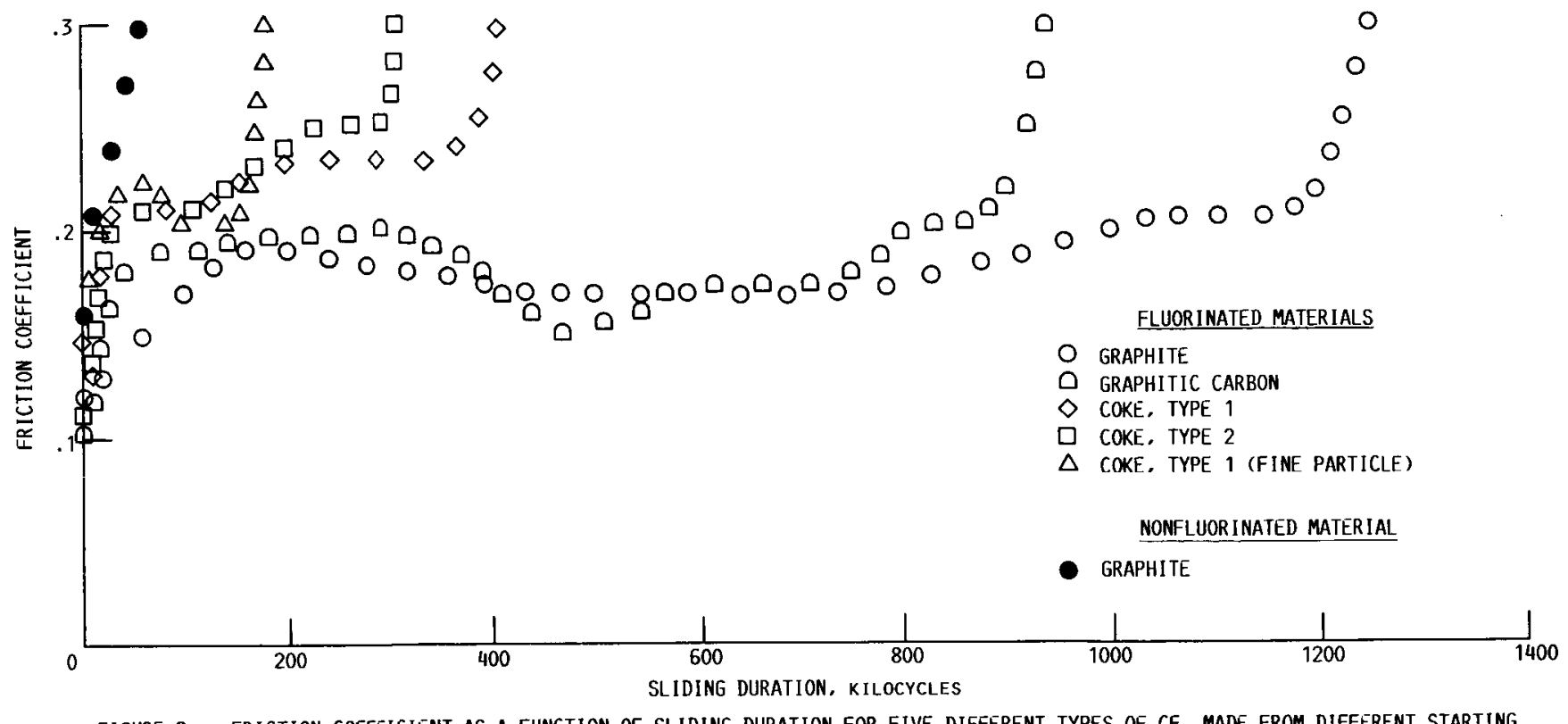

FIGURE 8. - FRICTION COEFFICIENT AS A FUNCTION OF SLIDING DURATION FOR FIVE DIFFERENT TYPES OF CF $X$ MADE FROM DIFFERENT STARTING MATERIALS, GRAPHITE IS ALSO GIVEN AS A COMPARISON.

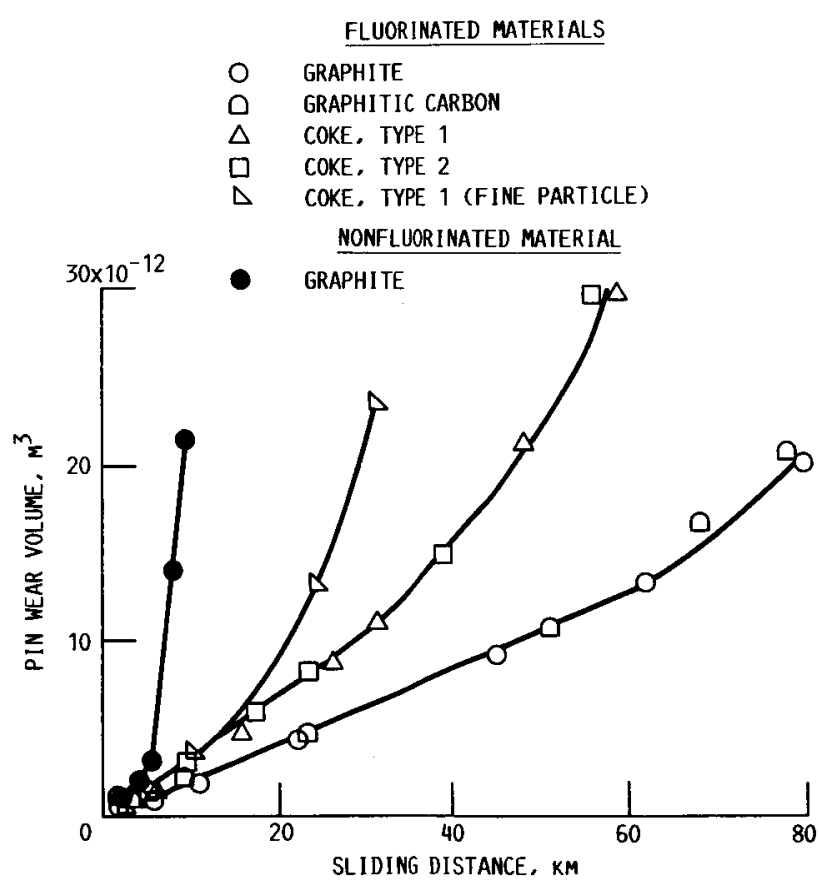

FIGURE 9. - PIN WEAR VOLUNE AS A FUNCTION OF SLIDING DISTANCE FOR FIVE DIFFERENT TYPES OF FLUORINATED GRAPHITE AND CARBON. GRAPHITE IS ALSO GIVEN FOR COMPARISON.

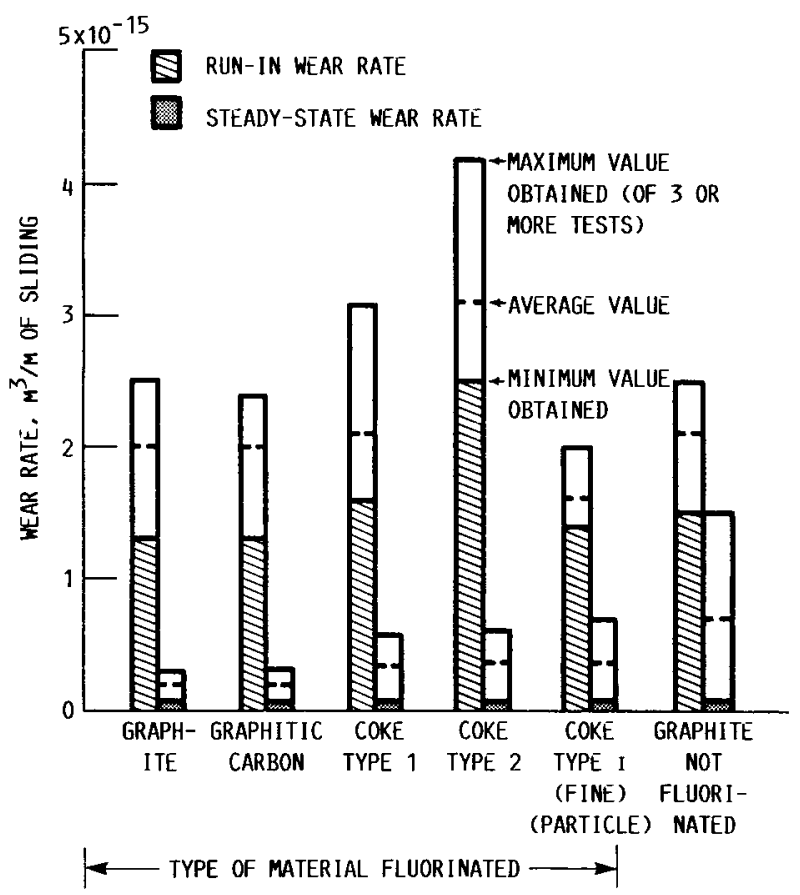

FIGURE 10, - RUN-IN AND STEADY-STATE WEAR RATES FOR $440 \mathrm{C}$ HT STAIMLESS STEEL PINS WHICH SLID AGAINST FIVE DIFFERENT TYPES OF GRAPHITE AND COKE WHICH WERE FLUORINATED TO PRODUCE A CF $X$ TYPE OF MATERIAL. THE SAME GRAPHITE BUT WHICH WAS NOT FLUORINATED IS SHOWN AS A COMPARISON. 


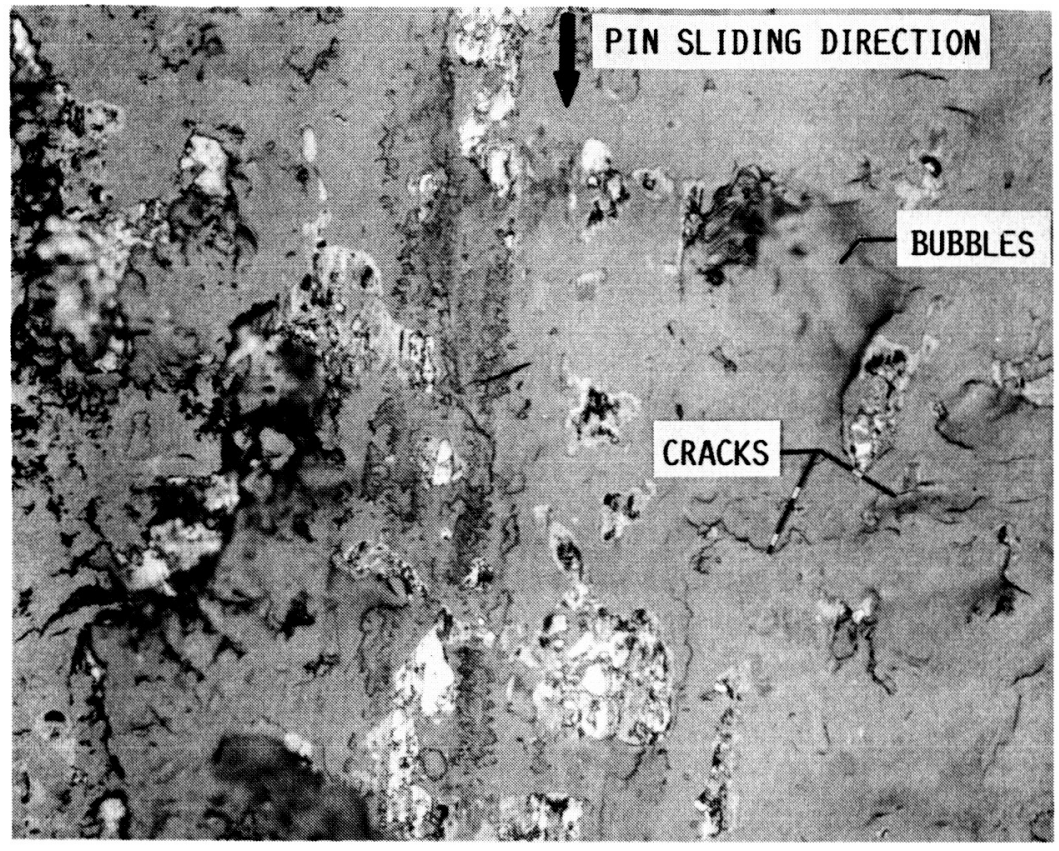
ORIGINAL PEOT
OF POOR QUALITY

(A) 10 KILOCYCLES OF SLIDING.

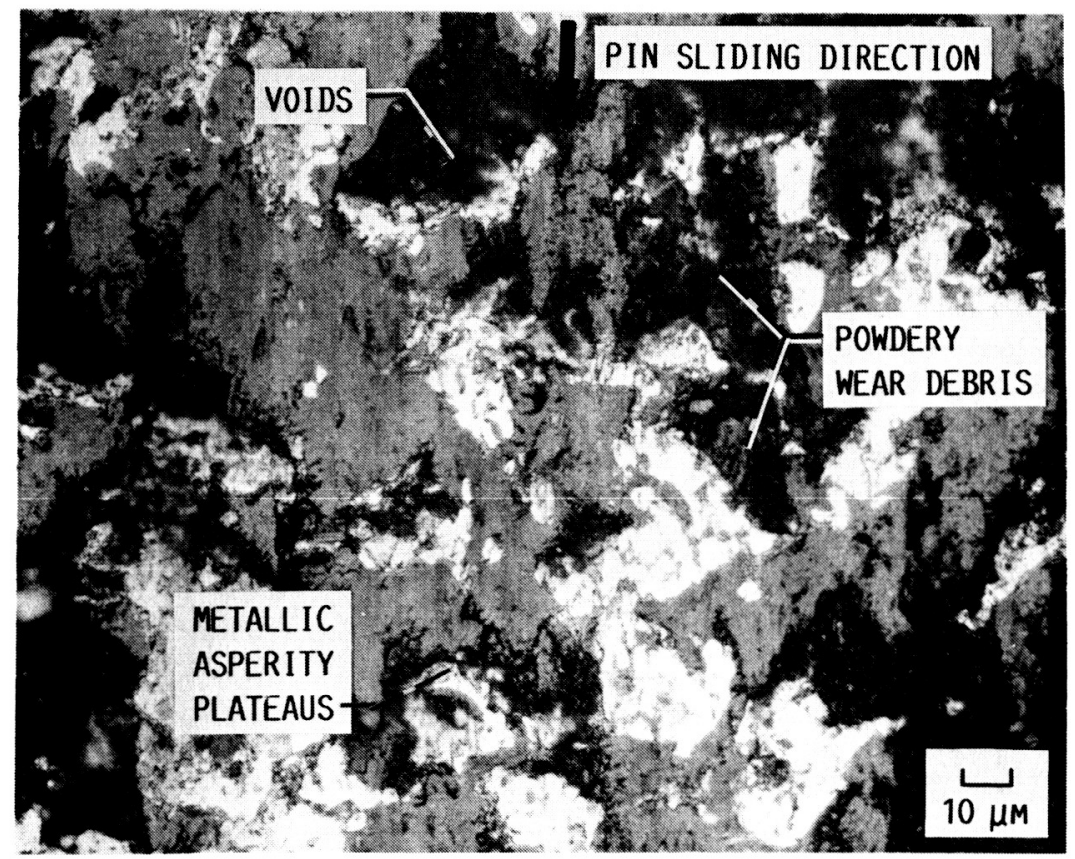

(B) 62 KILOCYCLES OF SLIDING.

FIGURE 11. - HIGH MAGNIFICATION PHOTOMICROGRAPHS OF THE WEAR TRACK ON NONFLUORINATED GRAPHITE FILMS APPLIED TO ROUGHENED 440C HT STAINLESS STEEL SUBSTRATES AFTER TWO SLIDING INTERVALS. 


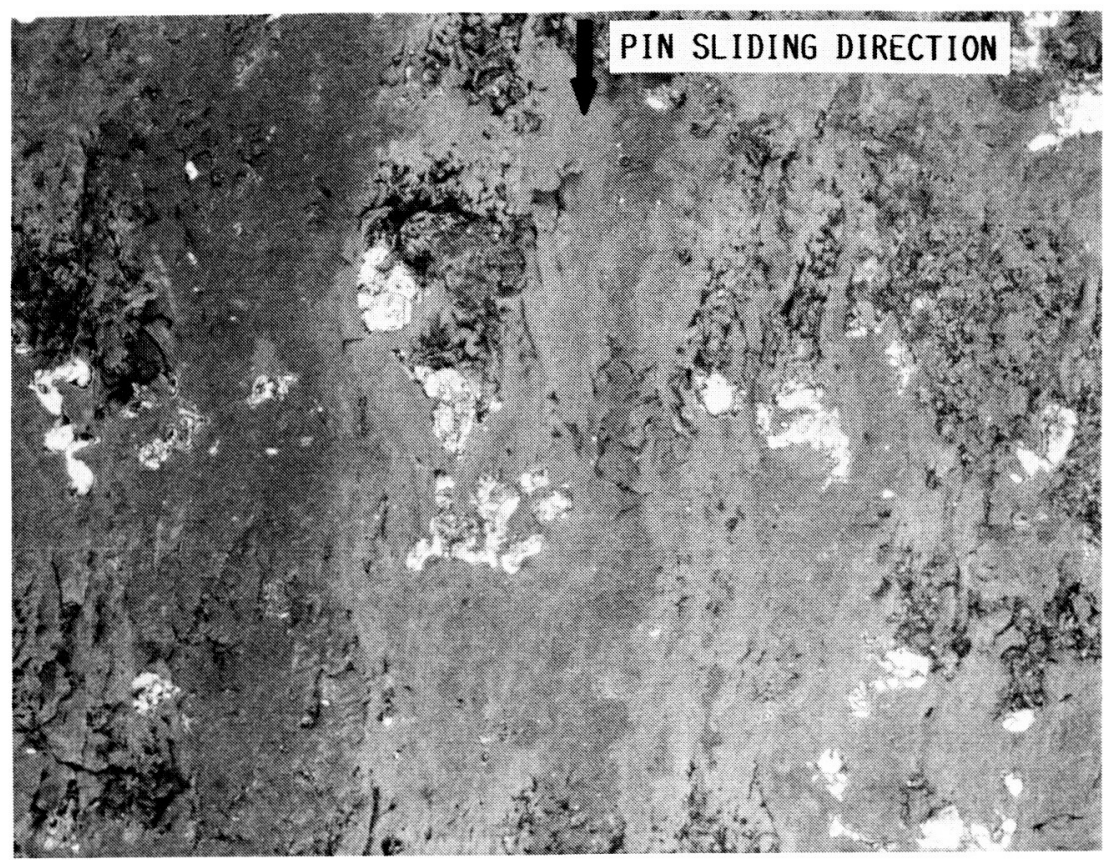

(A) 10 KILOCYCLES OF SLIDING.

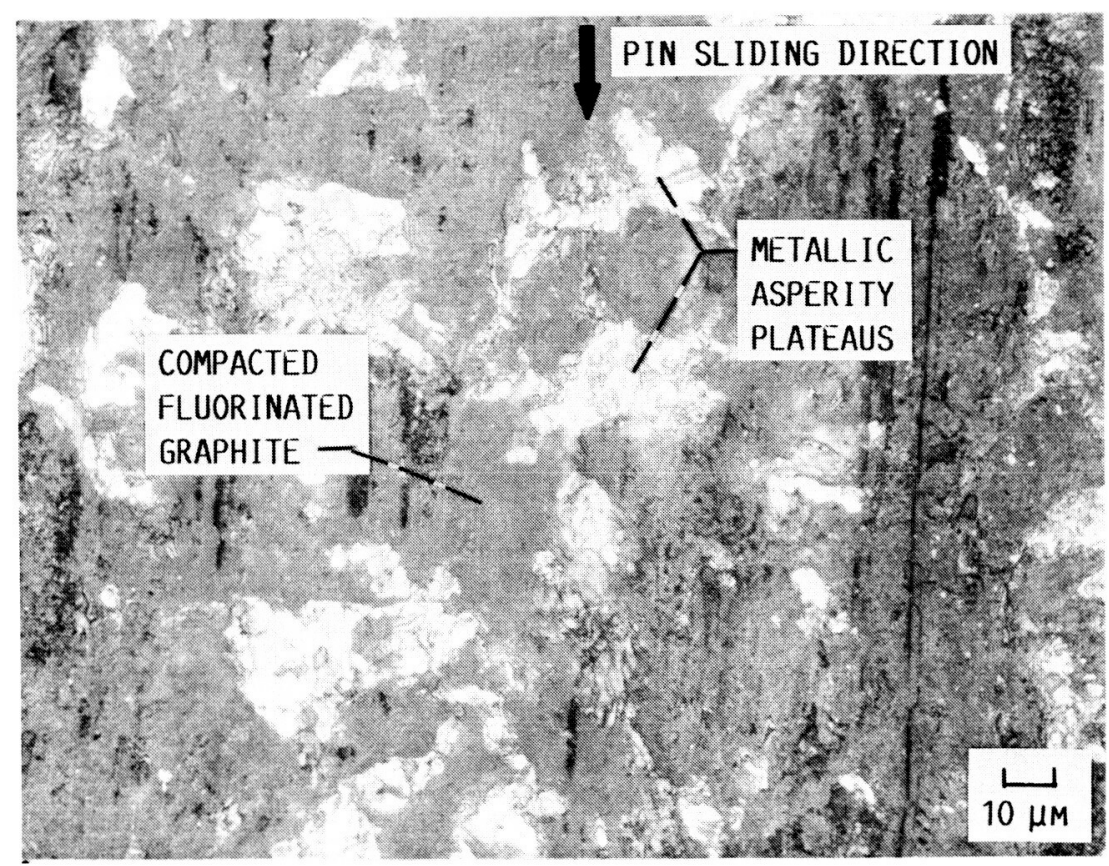

(B) 600 KILOCYCLES OF SLIDING.

FIGURE 12. - HIGH MAGNIFICATION PHOTOMICROGRAPHS OF THE WEAR TRACK ON FLUORINATED GRAPHITE FILMS APPLIED TO ROUGHENED $440 \mathrm{C}$ HT STAINLESS STEEL SUBSTRATES AFTER TWO INTERVALS OF SLIDING. 
ORICINAL PAOE IS

OF POOR QUALITY

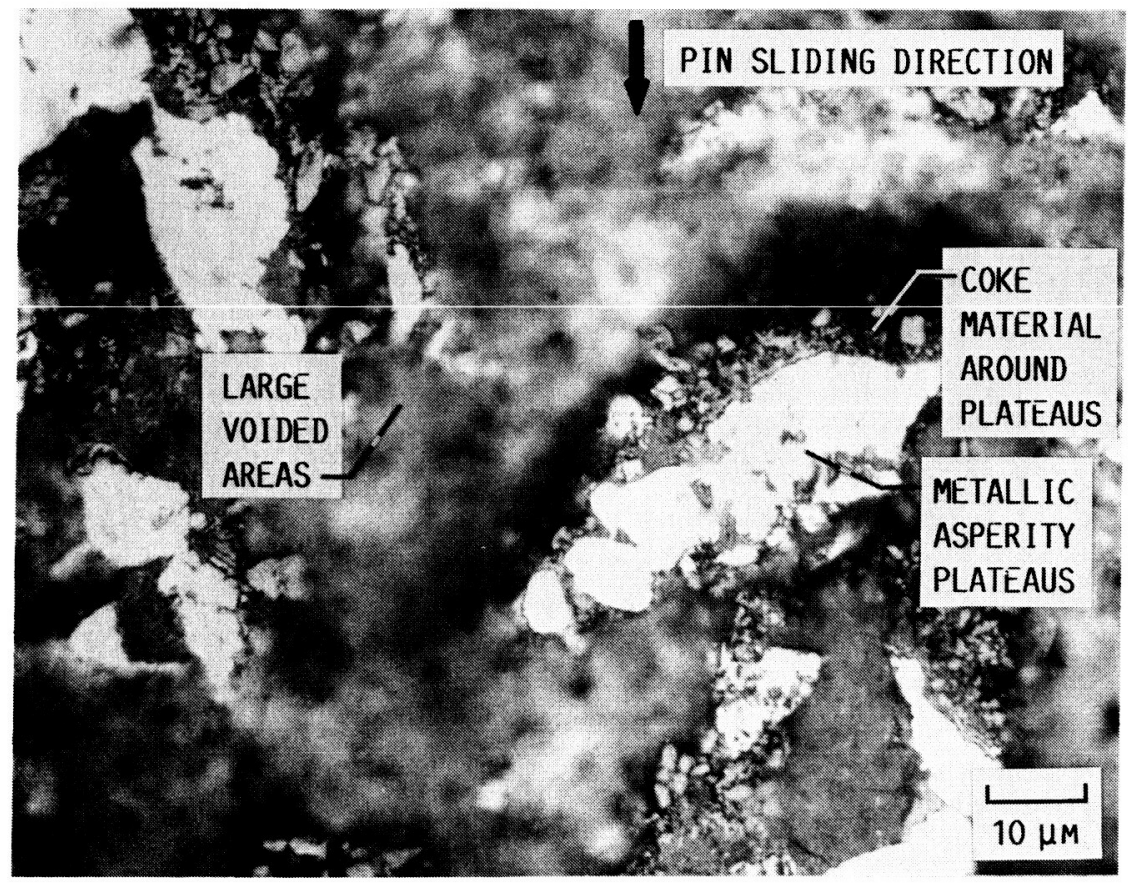

FIGURE 13. - HIGH MAGNIFICATION PHOTOMICROGRAPH OF THE WEAR TRACK ON THE NONFLUORINATED COKE FILM AFTER $1 \mathrm{kC}$ OF SLIDING. 


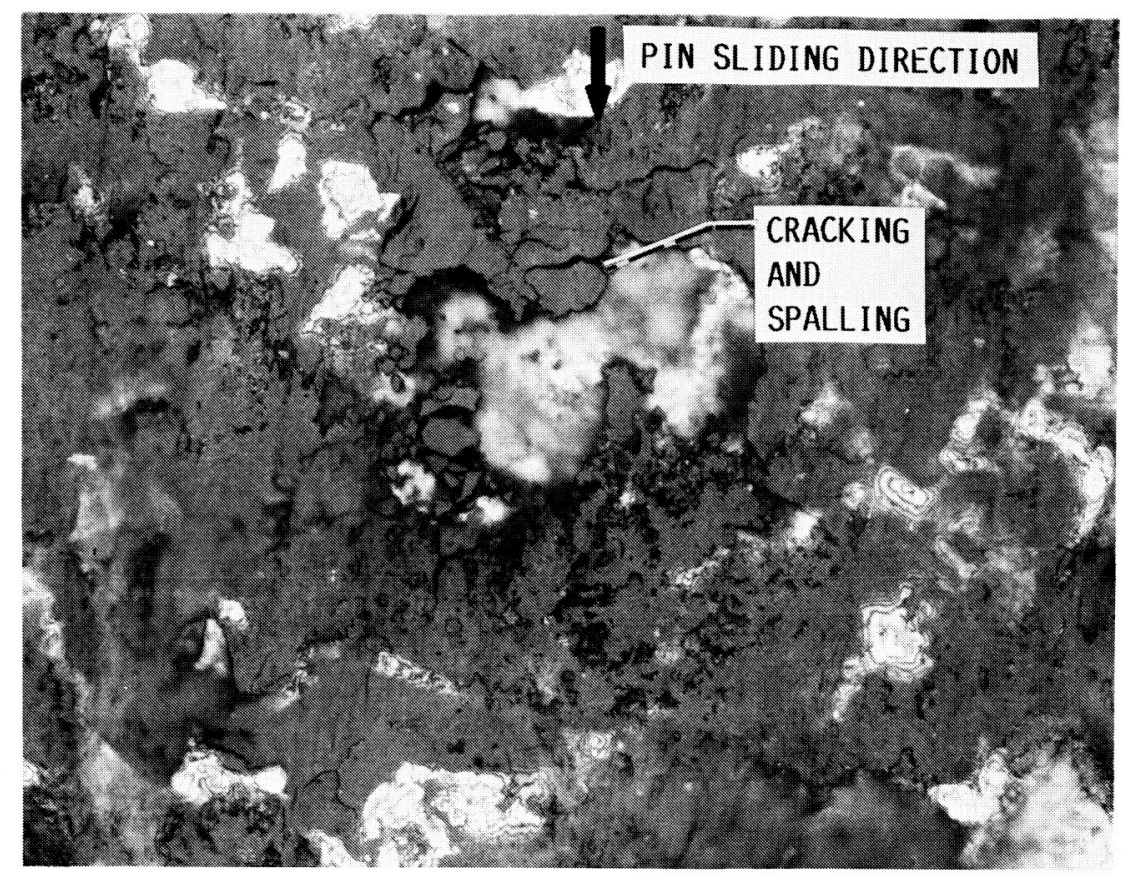

(A) 1 KILOCYCLE OF SLIDING.

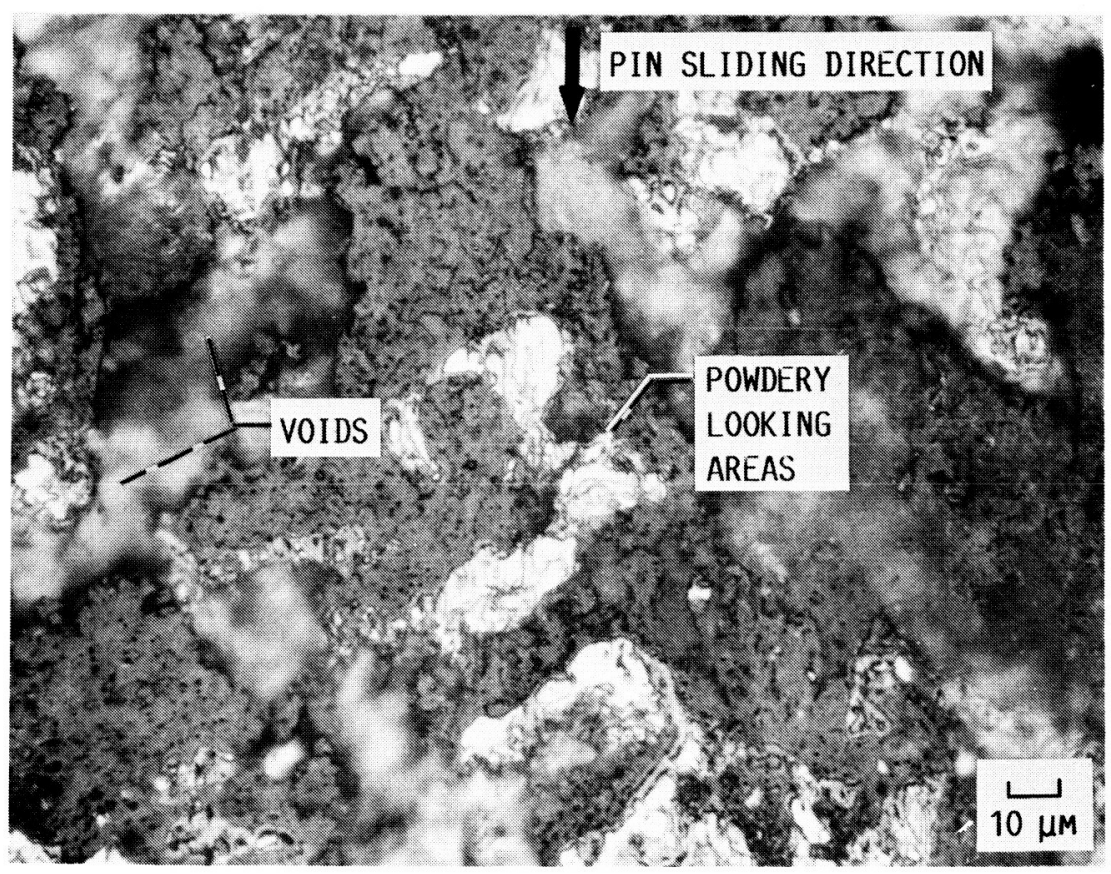

(B) 60 KILOCYCLES OF SLIDING.

FIGURE 14. - HIGH MAGNIFICATION PHOTOMICROGRAPHS OF THE WEAR TRACK ON THE FLUORINATED TYPE 1 COKE FILMS WHICH WERE APPLIED TO ROUGHENED 440D HT STAINLESS STEEL SUBSTRATES.

Ointh the OF POOR QuRTY 


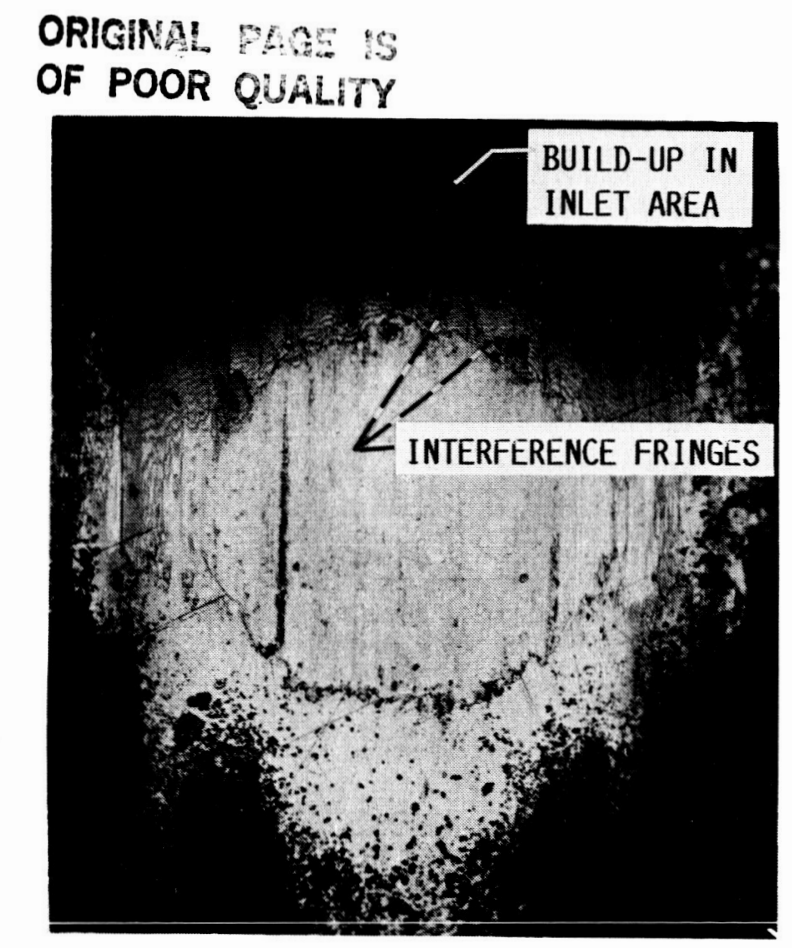

(A) NONFI IIORINATFD GRAPHITF

(B) FLUORINATED GRAPHITE.
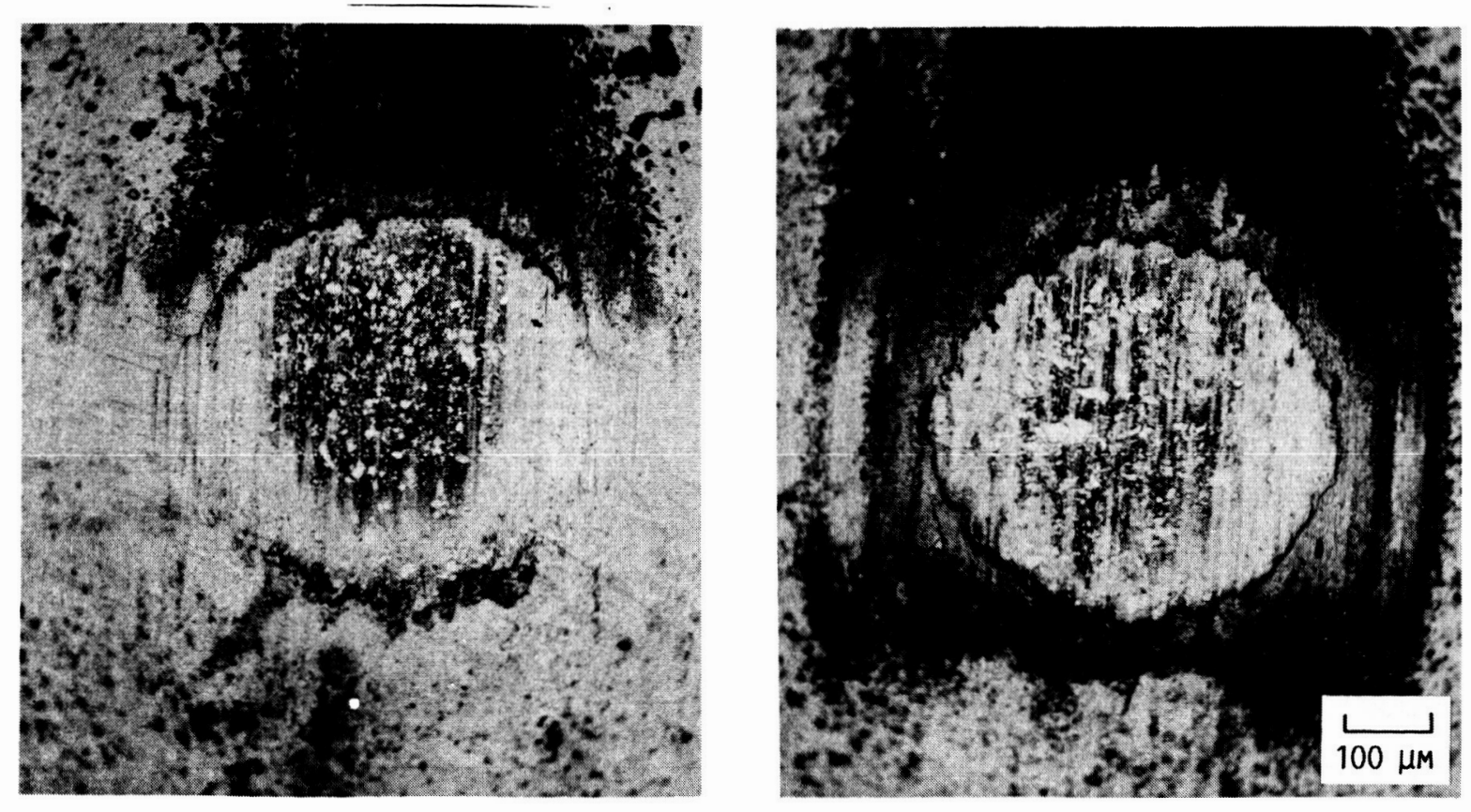

(C) FLUORINATED COKE.

(D) FLUORINATED SMALL PARTICLE COKE.

FIGURE 15. - PHOTOMICROGRAPHS OF 440C HT STAINLESS STEEL PIN WEAR SCARS AFTER 1 KILOCYCLE OF SLIDING AGAINST RUBBED SOLID LUBRICANT FILMS APPLIED TO ROUGHENED 440C HT STAINLESS STEEL DISKS. 


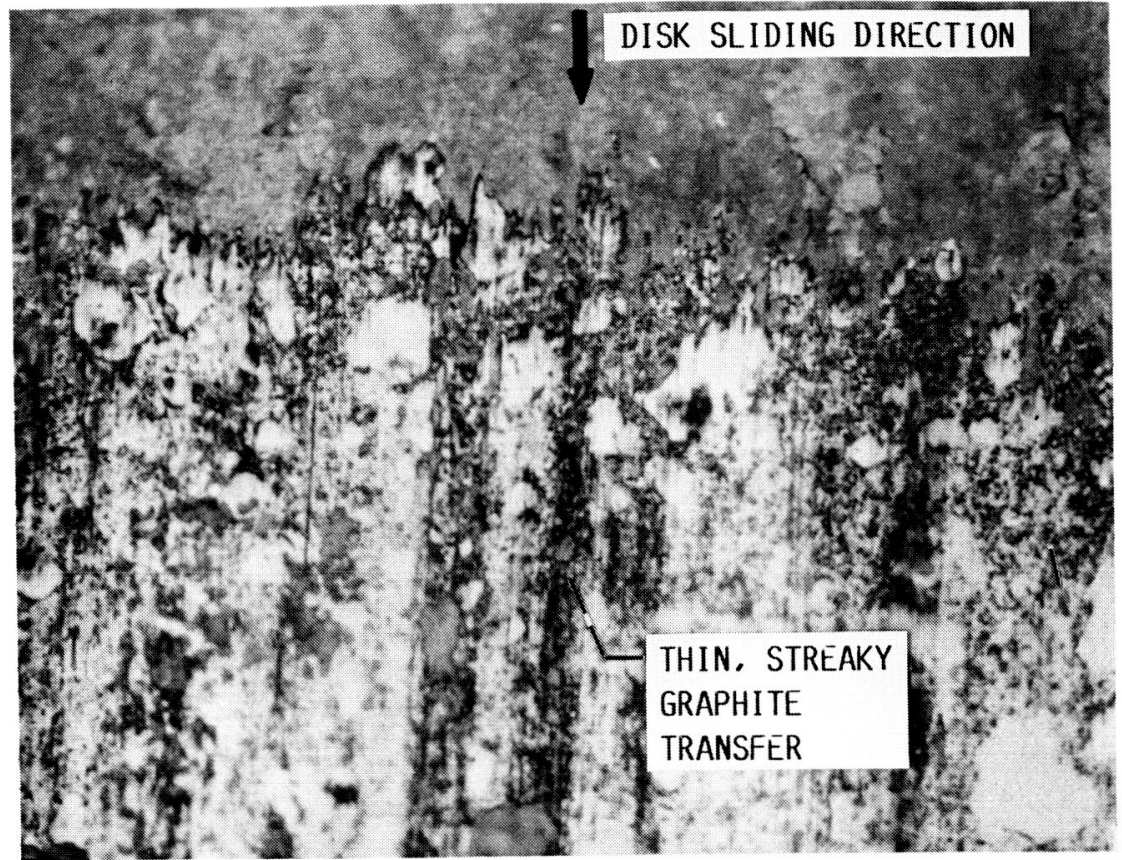

(A) 1 KILOCYCLE OF SLIDING.

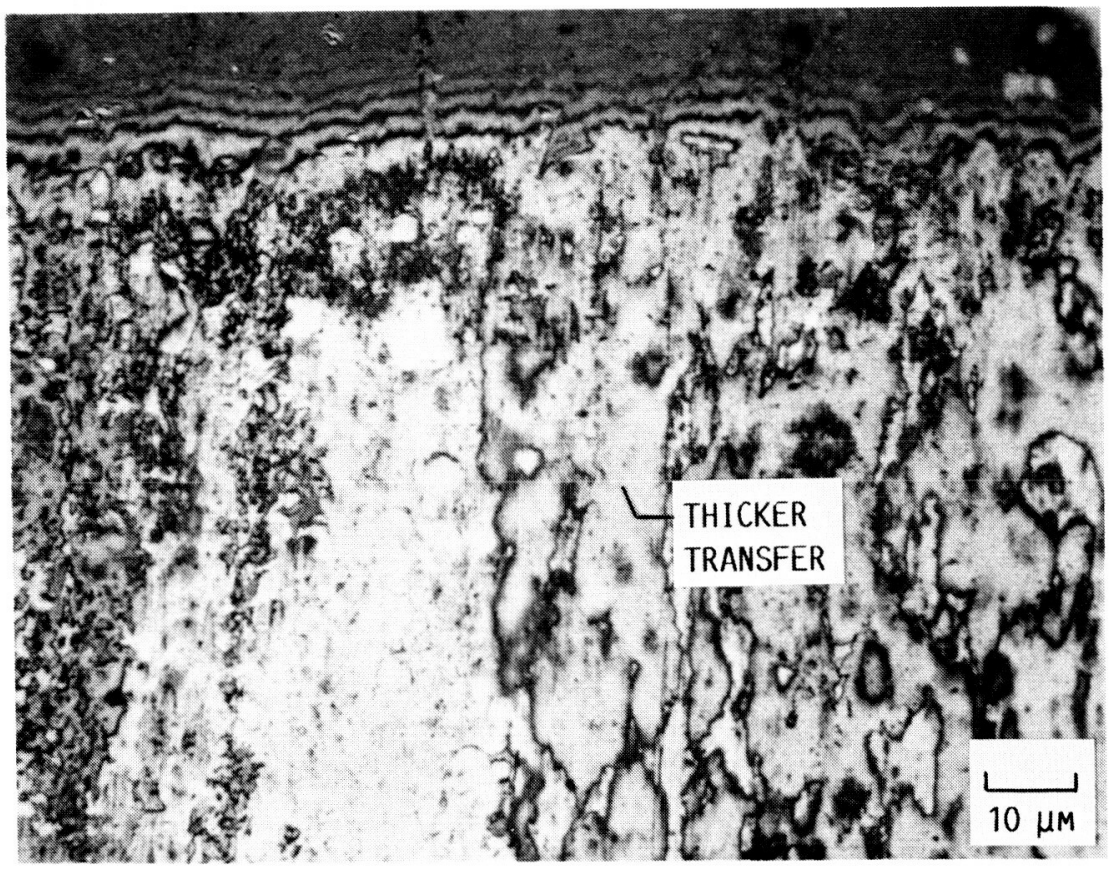

(B) 30 KILOCYCLES OF SLIDING.

FIGURE 16. - HIGH MAGNIFICATION PHOTOMICROGRAPHS OF THE TRANSFER TO $440 C$ HT STAINLESS STEEL PIN WEAR SCARS AFTER SLIDING AGAINST RUBBED FILMS OF NONFLUORINATED GRAPHITE FOR 1 AND 30 KILOCYCLES OF SLIDING.

ORIGINAL PROS IS

OF POOR QUALITY 


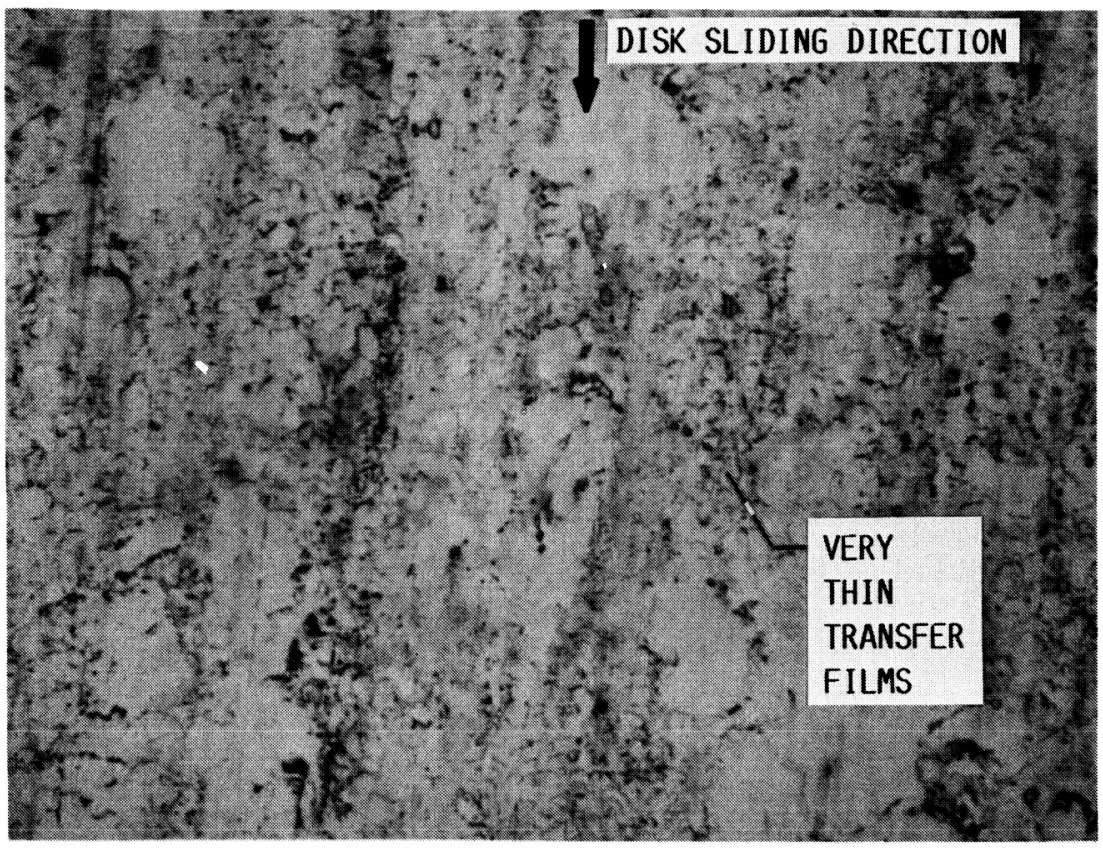

ORIGINAL PROE IS
OF. POOR QUALTY

(A) 10 KILOCYCLES OF SLIDING.

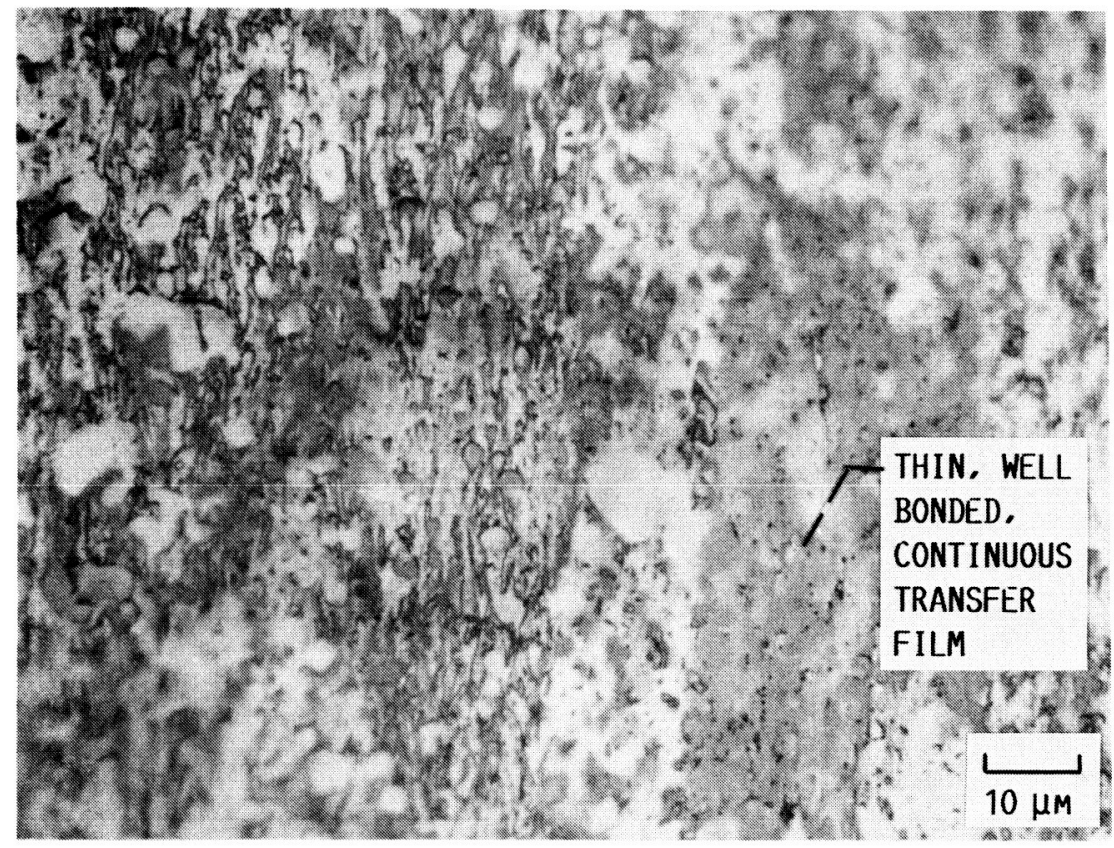

(B) 320 KILOCYCLES OF SLIDING.

FIGURE 17. - HIGH MAGNIFICATION PHOTOMICROGRAPHS OF THE TRANSFER TO $440 C$ HT STAINLESS STEEL PIN WEAR SCARS AFTER SLIDING AGAINST RUBBED FILMS OF FLUORINATED GRAPHITE FOR 10 AND 320 KILOCYCLES OF SLIDING. 


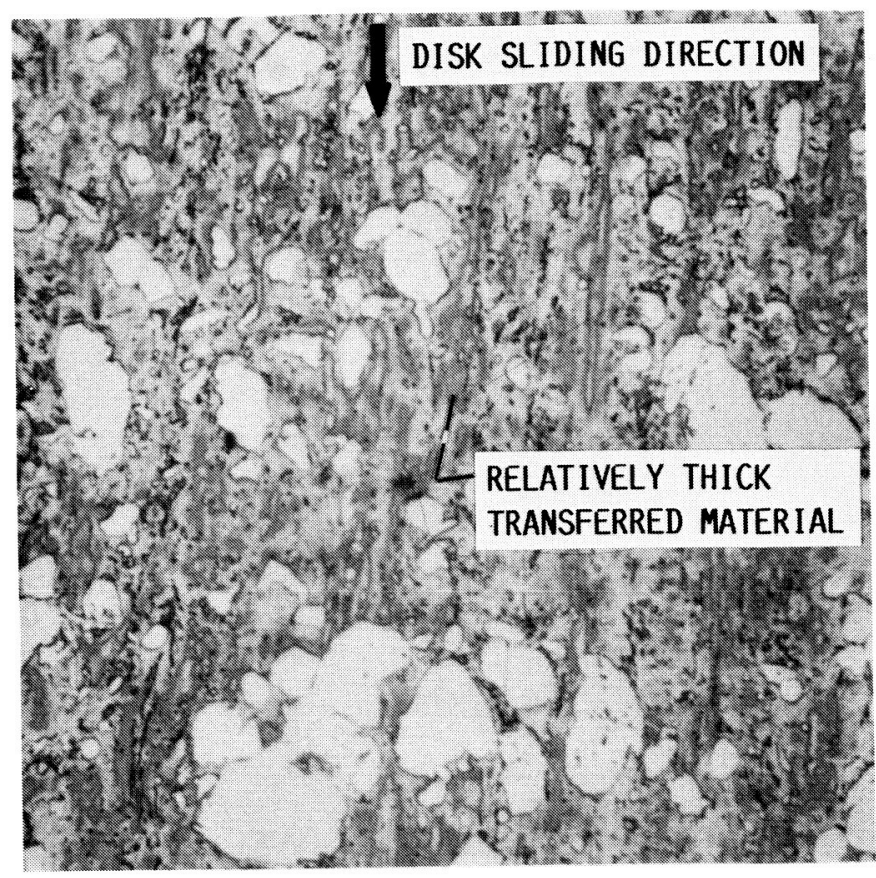

(A) 1 KILOCYCLE OF SLIDING.

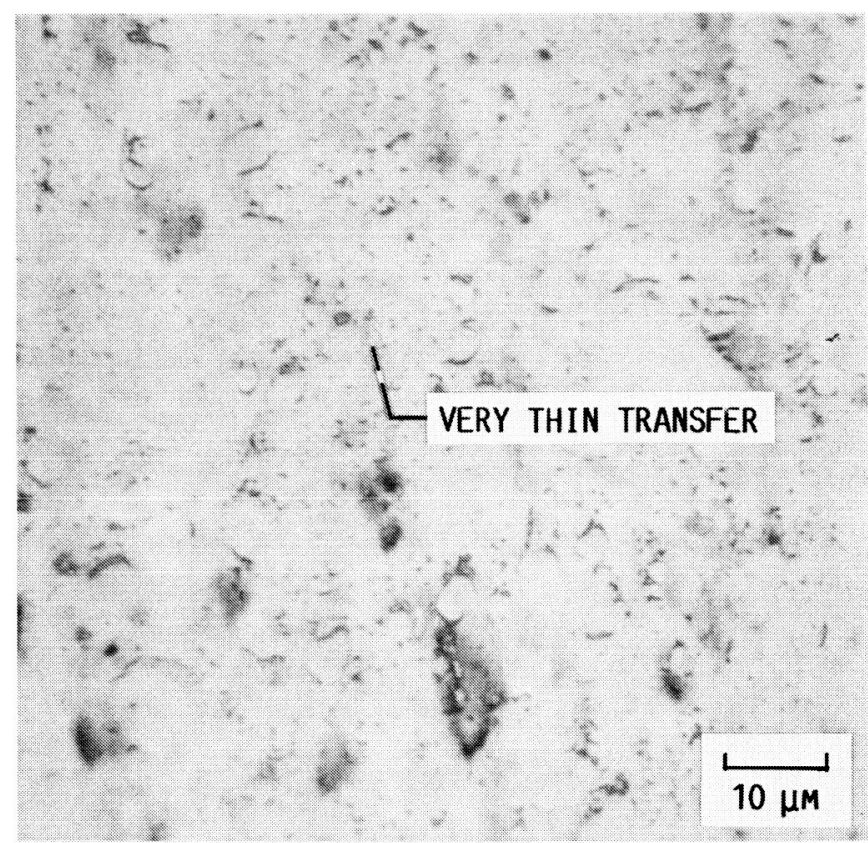

(B) 30 KILOCYCLES OF SLIDING.

FIGURE 18. - HIGH MAGNIFICATION PHOTOMICROGRAPHS OF THE TRANSFER TO $440 \mathrm{C}$ HT STAINLESS STEEL PIN WEAR SCARS AFTER SLIDING AGAINST RUBBED FILMS OF FLUORINATED TYPE 1 COKE FOR 1 AND 30 KILOCYCLES OF SLIDING. 


\begin{tabular}{|c|c|c|c|c|}
\hline \multicolumn{5}{|c|}{ Report Documentation Page } \\
\hline $\begin{array}{l}\text { 1. Report No. } \\
\text { NASA TM-100170 }\end{array}$ & \multicolumn{2}{|c|}{ 2. Government Accession No. } & \multicolumn{2}{|c|}{ 3. Recipient's Catalog No. } \\
\hline \multirow{3}{*}{\multicolumn{3}{|c|}{$\begin{array}{l}\text { 4. Title and Subtitle } \\
\text { Comparison of the Tribological Properties of } \\
\text { Fluorinated Cokes and Graphites }\end{array}$}} & \multirow{2}{*}{\multicolumn{2}{|c|}{ 5. Report Date }} \\
\hline & & & & \\
\hline & & & \multicolumn{2}{|c|}{$\begin{array}{l}\text { 6. Performing Organization Code } \\
505-63-01\end{array}$} \\
\hline \multirow{2}{*}{\multicolumn{3}{|c|}{$\begin{array}{l}\text { 7. Author(s) } \\
\text { Robert L. Fusaro }\end{array}$}} & \multicolumn{2}{|c|}{$\begin{array}{l}\text { 8. Performing Organization Report No. } \\
\text { E-3735 }\end{array}$} \\
\hline & & & \multicolumn{2}{|l|}{ 10. Work Unit No. } \\
\hline \multirow{3}{*}{\multicolumn{3}{|c|}{$\begin{array}{l}\text { 9. Performing Organization Name and Address } \\
\text { National Aeronautics and Space Administration } \\
\text { Lewis Research Center } \\
\text { Cleveland, Ohio } 44135\end{array}$}} & \multirow{2}{*}{\multicolumn{2}{|c|}{ 11. Contract or Grant No. }} \\
\hline & & & & \\
\hline & & & \multirow{2}{*}{\multicolumn{2}{|c|}{$\begin{array}{l}\text { 13. Type of Report and Period Covered } \\
\text { Technical Memorandum }\end{array}$}} \\
\hline \multirow{2}{*}{\multicolumn{3}{|c|}{$\begin{array}{l}\text { 12. Sponsoring Agency Name and Address } \\
\text { National Aeronautics and Space Administration } \\
\text { Washington, D.C. } 20546\end{array}$}} & & \\
\hline & & & \multicolumn{2}{|c|}{ 14. Sponsoring Agency Code } \\
\hline \multicolumn{5}{|c|}{$\begin{array}{l}\text { 15. Suppiementary Notes } \\
\text { Prepared for the } 1988 \text { Annual Meeting of the Society of Tribologists and Lubrica- } \\
\text { tion Engineers, Cleveland, Ohio, May } 9-12,1988 \text {. }\end{array}$} \\
\hline \multicolumn{5}{|c|}{$\begin{array}{l}\text { 16. Abstract } \\
\text { The friction, wear, endurance life, and surface morphology of rubbed (burnished) } \\
\text { fluorinated graphite and fluorinated coke materials were studied. Two different } \\
\text { coke powders, a graphitic carbon powder, and a graphite powder were fluorinated } \\
\text { and then tribologically investigated. In addition, one of the coke powders was } \\
\text { reduced in size before fluorinating to evaluate the effect of a finer particle } \\
\text { size on the tribological properties. For comparison, graphite and coke powders } \\
\text { which were not fluorinated were also tribologically evaluated. Elemental analy- } \\
\text { sis by emission spectroscopy was performed on each sample to determine the } \\
\text { impurity content and X-ray diffraction analysis was performed to determine the } \\
\text { crystallinity. coke was found to have very little lubricating ability, but } \\
\text { fluorinated coke did possess good lubricating properties. However, the fluori- } \\
\text { nated graphite and fluorinated graphitic carbon (which gave equivalent results) } \\
\text { gave superior results to those obtained with the fluorinated cokes. No tribo- } \\
\text { logical benefit was found for using small versus a larger particle size of coke, } \\
\text { at least when evaluated as a rubbed film. }\end{array}$} \\
\hline \multirow{2}{*}{\multicolumn{2}{|c|}{$\begin{array}{l}\text { 17. Key Words (Suggested by Author(s)) } \\
\text { Fluorinated graphite; Carbon mono- } \\
\text { fluoride; Solid lubricants; Friction; } \\
\text { Wear; Transfer films; Lubricating films }\end{array}$}} & \multirow{2}{*}{\multicolumn{3}{|c|}{$\begin{array}{l}\text { 18. Distribution Statement } \\
\text { Unclass ified - unl imited } \\
\text { STAR Category } 27\end{array}$}} \\
\hline & & & & \\
\hline $\begin{array}{l}\text { 19. Security Classif. (of this report) } \\
\text { Unclass if i ed }\end{array}$ & $\begin{array}{l}\text { 20. Socurity Classif. (of t } \\
\text { Unc l }\end{array}$ & ifie & $\begin{array}{r}\text { 21. No of pages } \\
31\end{array}$ & $\begin{array}{r}\text { 22. Price* } \\
\mathrm{AO} 3\end{array}$ \\
\hline
\end{tabular}

